\title{
Atatürk'ün Güzel Sanatlara ve Sanatçılara Bakışı
}

\section{Dr. Erol EVCIN*}

\begin{abstract}
"Sanatsız kalan bir milletin, hayat damarlarından biri kopmuş olur."
\end{abstract}

(K.Atatürk, 1923)

\section{$\ddot{O z e t}$}

Güzel sanatlar, Atatürk’ün çağdaşlaşma anlayışı içinde önemli bir yer tutmuştur. Güzel sanatlarda elde edilecek başarlları Türk İnklâbı'nın başarısına bir ölçü olarak kabul eden Atatürk, bu suretle yüzylllardır ihmal edilmiş birçok sanat dalına özel ilgi göstermiş, çă̆daş Türkiye Cumhuriyeti'nin bu değerler üzerinde yükselebileceğine inanmıştır. Böylelikle Cumhuriyet'in ilk yıllarından itibaren yapılan yasal düzenlemeler ve tesis edilen yeni eğitim kurumları vasıtasıla sanatın ve sanatçıların yolu açılmış, millî kültür ile çağdaş esasları içinde barındıran özgün sanat eserleri verilmeye başlanmıştır.

Bu bă̆lamda çalışmamızda, Atatürk'ün güzel sanatlara ve sanatçllara verdiği önem üzerinde durulmuş ve söz konusu anlayış çerçevesinde Türkiye Cumhuriyeti'nin sanatsal kimliğinin temellerinin atıldığı süreç ele alınmıştır.

Anahtar Kelimeler: Atatürk, Güzel Sanatlar, Sanatçı, Türk Inkılâbı, Çağdaşlaşma.

* T.C. Kültür ve Turizm Bakanlığı, Araştırma ve Eğitim Genel Müdürlüğü, Kültür ve Turizm Uzman1 


\begin{abstract}
Fine arts played an important role in the modernization understanding of Atatürk. Atatürk who accepted the successes which were gained in fine arts, as a criterion of the success of the Turkish reforms, supported the many artistic branches which were ignored for centuries and believed that the modern Turkish Republic shall rise over these arts and values. Therefore, thanks to the legal arrangements which were made as from the first years of the foundation of the Republic and the new educational institutions established, way of art and artist is opened and the original artistic works which accommodate modern principles and the national culture were started to be delivered.

The current study discusses and highlights the importance which was given by Atatürk to the fine arts and the artists and the process through which foundations of the artistic identity of the Republic of Turkey were laid down within the framework of the said understanding.
\end{abstract}

Key Words: Atatürk, Fine Arts, Artisan, Turkish Revolution, Modernization

\title{
Giriş
}

Çağdaş Türkiye'nin kurucusu Atatürk, 20. yüzyılın siyasi hayatına yön veren ender devlet adamlarından biri olarak tarihteki yerini almıştır. Atatürk'ü tarih içinde yücelten esas özelliği Türk İstiklâl Savaşı'nın muzaffer komutanı olmasından daha çok, inkılâpçı kişiliği olmuştur. Bu anlamda çalışmamızın başında Atatürk'ün çağdaşlaşma anlayışından kısaca bahsetmek yerinde olacaktır.

Atatürk, Türk İnk1lâbı'nı: “Türk milletini son asırlardan beri geri bırakmış olan müesseseleri yıkarak, yerlerine milletin en yüksek medenî icaplara göre ilerlemesini temin edecek yeni müesseseleri koymak", olarak tarif etmiş ve inkılâbın amacını: "Türkiye Cumhuriyeti halkını tamamen çağdaş ve bütün manâ ve görüntüsüyle medenî bir toplum hâline ulaştırmak" ş̧eklinde değerlendirmiştir. Bu tanım ve amaç doğrultusunda, Türk İstiklâl Savaşı'nın silahlı mücadele safhası bittikten hemen sonra daha büyük ve esaslı bir mücadele safhasına atılarak, Türk milletinin önüne:

\footnotetext{
1 Afet İnan, Atatürk Hakkında Hatıralar ve Belgeler, Türkiye İş Bankası yayınları, İstanbul, 2007, s.354.

2 Atatürk'ün Söylev ve Demeçleri, C.II, Türk İnkılâp Tarihi Enstitüsü yayınları, Ankara, 1997, s.224.
} 
"Türk kültürünü muasır medeniyet seviyesinin üzerine çıkarmak" ${ }^{3}$ ülküsünü koymuş ve bunu bir hayat davası olarak görmüştür. ${ }^{4}$

$\mathrm{Bu}$ nedenle, geleneksel yaşam tarzının gelişime engel teşkil eden menfi yönlerini yok etmek, yeni kuşakları çağdaş yaşama uygun kural ve kurumlarla yetiştirmek ve gelenekle çağ arasında köprü kurmak yeni Türkiye Cumhuriyeti'nin temel hedefleri arasında yer almıştır. Böylece Osmanlı Devleti'nden devralınan siyasal, sosyal, hukuksal, kültürel kurumlar ve estetik hayat biçimi muasır medeniyet seviyesini temsil eden Batı kurum ve değerleri temel alınarak değiştirilmiştir. ${ }^{5}$ Söz konusu değişim, Batı taklitçiliği olmaktan uzak özgün bir süreci ifade etmiştir. Çünkü bizzat Atatürk'ün belirttiği üzere, Türk İnkılâbı'nda milletin bünyesine uygun olan değerler dünya medeniyet seviyesi içinde benimsenmiştir. ${ }^{6}$ Batı kurum ve değerleri bir amaç değil, araç olarak kabul görmüştür. Çağdaşlaşmanın yozlaşmaması, millî değerlerle bezenmesi için de tarih ile beslenen bir tabana oturtulmasına özen gösterilmiştir. ${ }^{7}$ Şunu da vurgulamak gerekir ki Cumhuriyet'in ilk yıllarındaki bu değişim süreci Osmanlı Devleti'ndeki yenileşme hareketleri gibi bir derece farkından ziyade, mahiyet farkı arz etmiştir. ${ }^{8}$

İnkılâba bakış açısından da anlaşılacağı üzere Atatürk, çağdaşlaşmayı bir bütün olarak görmüş ve bu doğrultuda devlet ile milleti eylemli olarak inkılâp hareketine katmıştır. Bu harekette ve yeni şekillenmede kültürel dinamikler ile ekonomik, siyasal, toplumsal ve psikolojik değişmeler iç içe geçmiş, birbirini desteklemiş ve güçlü kılmıştır. ${ }^{9}$

Atatürk'ün bir bütün teşkil eden çağdaşlaşma anlayışı içinde güzel sanatlar, Türk İnkılâbı'nın tamamlayıcı bir unsurunu ve önemli bir merhalesini teşkil etmiştir. Atatürk, ancak güzel sanatlarda ilerleyen ve eser veren milletlerin asrin ileri medeniyetleri arasında yer alabileceklerini belirtmiştir. ${ }^{10}$ Medeniliğin ve ileriliğin bir göstergesi olan güzel sanatlar bu

\footnotetext{
${ }^{3}$ Atatürk'ün Söylev ve Demeçleri, C.II, s.318.

${ }^{4}$ Atatürk'ün Söylev ve Demeçleri, C.III, s.94-95.

${ }^{5}$ İzzet Öztoprak, "Atatürk, Çağdaşlaşma ve Dış Dünyaya Etkileri”, Atatürk Araştırma Merkezi Dergisi, C.I, Ankara, Kasım 1984, s.290.

${ }^{6}$ İnan, a.g.e., s. 243.

7 Azmi Süslü, "Cumhuriyet Döneminin Türk Kültürüne Bakışı ve Kültür Politikalarl”, Atatürk Araştırma Merkezi Dergisi, C.XI, S.31, Mart 1995.

${ }^{8}$ Öztoprak, a.g.m., s.292.

9 Suna Kili, Atatürk Devrimi, Bir Çağdaşlaşma Modeli, Türkiye İş Bankası Kültür yayınlar1, Ankara, 2000, s.112 ve 118 .

${ }_{10}$ Afet İnan, “Atatürk'ün Güzel Sanatlara Verdiği Önem”, Devlet Tiyatrosu, C.39, Ankara, 1968, s.5.
} 
yönüyle çağdaşlaşmanın ana kıstaslarından biridir. ${ }^{11} \mathrm{Bu}$ yüzden güzel sanatlar alanında gösterilecek başarıyı ve atılımları inkılâbın temel amaçlarından ve dinamiklerinden birisi olarak gören Atatürk: "Bir millet ki resim yapmaz, heykel yapmaz, bilimin gerektirdiği şeyleri yapmaz; itiraf etmeli ki o milletin ilerleme yolunda yeri yoktur. Oysaki bizim ulusumuz, gerçek nitelikleriyle uygarlı̆̆a erişmeye lâylktır, uygarlı̆̆a erişecektir ve ilerleyecektir. "I2 ş̧eklindeki söylemiyle bu konu hakkındaki düşüncelerini özlü bir şekilde ifade etmiştir.

Türk İnkılâbı, milliyetçilik ve medeniyetçilik gibi iki temel prensip üzerine inşa edilmiştir. ${ }^{13} \mathrm{Bu}$ bağlamda Atatürk, güzel sanatlar alanında da millî ve medenî özelliklere sahip bir sanat tarzının arayışı içinde olmuştur. Kopyacı, taklitçi ve tercümeci bir sanat anlayışını reddeden bu yaklaşımda, kaynağını halktan aldığı değer yargılarını muasır medeniyet seviyesini temsil eden Batı tekniği ile işlemek ve özgün bir Türk sanatı yaratmak esas hedeftir. ${ }^{14}$

Atatürk, güzel sanatları eğitim, bilim ve kültür inkılâbının bir parçası olarak görmüş ve Türk sanatının açılacak eğitim kurumları vasıtasıyla gelişimini sürdürerek milletin fikrî terbiyesinde, siyasi ve sosyal hayatında önemli bir rol üstleneceğini belirtmiştir. ${ }^{15}$ Fikirlerin ve inkılâpların yaygınlaşması, topluma mâl olması konusunda da en etkin yolun sanat olduğunu vurgulamıştır. ${ }^{16}$

Türkler, tarihin en köklü ve büyük milletleri arasında yer almış olmalarına rağmen Batı'ya yakın zamanlara kadar bir Türk kültür varlığını kabul ettirmekte zorluk çekmişler ve Batı'da, Türk sanatının özgün bir kimliğe sahip olmayıp İslâm, Arap, İran ve Bizans sanatlarından mülhem olduğu kanısı yaygınlaşmıştır. Güzel sanatlara karşı birçok Osmanlı Padişahı'nın ilgisi olmasına ve özellikle Tanzimât döneminden itibaren söz konusu alanda birçok yenilik hareketine girişilmesine rağmen, bu süreç Osmanlı Devleti'ndeki diğer yenileşme hareketleri gibi yüzeysel ve sı̆̆ kalmış; güzel sanatların birçok dalının halk tarafından benimsenmesi, tabana

\footnotetext{
${ }^{11}$ Temuçin Faik Ertan ve diğerleri, Başlangıcından Günümüze Türkiye Cumhuriyeti Tarihi, Siyasal Kitabevi, Ankara, 2011, s.202.

${ }^{12}$ Atatürk'ün Söylev ve Demeçleri, C.II, s.71

13 Peyami Safa, Türk İnkılâbına Bakışlar, Atatürk Araştırma Merkezi yayını, Ankara, 1996, s.54.

${ }^{14}$ Enver Behnan Şapolyo, Kemal Atatürk ve Millî Mücadele Tarihi, Ekicigil matbaası, 3. bask1, İstanbul, 1958. Benzer bir yaklaşım için bkz.; Temuçin Faik Ertan ve diğerleri, a.g.e., s.202.

${ }_{15}$ İnan, a.g.e., s. 84

${ }^{16}$ Atatürk’ün Söylev ve Demeçleri, C.II, s.47.
} 
yayılması ve kurumsallaşması mümkün olamamıștır. Ayrıca Osmanlı Devleti'nin çöküş yıllarında halk arasında belirginleşen yeniliğe ve değişime karşı temkinli yaklaşım birçok sanat dalının ihmal edilmesine yol açmış, gelişmesine engel teşkil etmiştir. ${ }^{17}$

Bu noktada şunu açıkça ifade edebiliriz ki Türk sanatı ile ilgili esaslı ve etkili hamleler ancak Atatürk ve O'nun yüksek ideallerle kurduğu Cumhuriyet tarafından gerçekleştirilebilmiştir. ${ }^{18}$ Cumhuriyet' in ilk yıllarında yeni Türk Devleti'ne modern devlet örgütleri kazandırılırken, Türk sanatının çağdaş anlamda gelişmesi ve ilerlemesi için yeni bir anlayış benimsenmiş ${ }^{19}$ ve bu konuda devlet ile millet ortak hedefler doğrultusunda bütünleşmiştir.

10. Y1l Nutku'nda Türkiye Cumhuriyeti'nin temelinin Türk kültürü olduğunu beyan eden Atatürk: "Türk milletinin tarihi vasfi da güzel sanatları sevmek ve onda yükselmektir. Bunun içindir ki, milletimizin yüksek karakterini, yorulmaz çalışkanlığını, fitrî zekâsını, ilme bağlılı̆̆ını, güzel sanatlara sevgisini, millî birlik duygusunu mütemadiyen her türlü vasita ve tedbirlerle besliyerek inkişâf ettirmek millî ülkümüzdür." diyerek millî hedeflere doğru yürümenin akılcı ve bilimsel yolunun güzel sanatları sevmekten ve bu alanda ilerlemekten geçtiğini belirtmiştir. Türk milletinin tarihte olduğu gibi medenî kabiliyetini dünyaya kabul ettirebilmesi ancak bu ülküye bağl11ıkla mümkün olabilecektir. ${ }^{20}$ Atatürk'ün 10 . Y1l Nutku gibi Cumhuriyet'in on yıllık muhasebesini yaptığ 1 ve gelecek nesillere yeni hedefler gösterdiği bir söyleminde güzel sanatlara da değinmiş olması konu hakkındaki hassasiyetini dile getiren önemli bir gösterge olarak anlaşılmalıdır.

Atatürk, güzel sanatlarda elde edilecek başarının bütün inkılâpların başarısının bir göstergesi olduğunu düşünmüştür. $\mathrm{Bu}$ alanda başarılı olamayan milletlerin, çağdaş dünyada kendilerine yer bulabilmelerini mümkün görmemiş, bu yüzden güzel sanatlara hassasiyetle eğilmiştir. ${ }^{21}$ Ressam İbrahim Çallı ile bir sohbeti sırasında: "güzel sanatlar; aynı milletin çocuklarının birbirlerini tanımalarını, sevmelerini ve böylece oluşacak

\footnotetext{
17 Oktay Aslanapa, “Atatürk'ün Kültür ve Sanat Faaliyetleri”, Erdem, C.II, S.6, Atatürk Kültür Merkezi yayını, (Ayrı basım), Ankara, 1987, s.741.

${ }^{18}$ İsmet Giritli, “Atatürk, Kültür ve Sanat”, Atatürk Araştırma Merkezi Dergisi, CIV, (Say1 10'dan ayrı basım), Ankara, Kasım 1987, s.23.

19 Latife Öztoprak, “Atatürk, Sanat, Sanatçı ve Resim”, Atatürk Araştırma Merkezi Dergisi, C.XIX, Ankara, Temmuz 2003, S.56, s.731.

${ }^{20}$ Atatürk'ün Söylev ve Demeçleri, C.II, s.318-319.

${ }^{21}$ Cumhuriyet Gazetesi, Cevat Abbas Gürer, "Montrö Imzalandığ Akşam Atatürk Bu Sulh Zaferini Florya'da Nasıl Kutlamıştı?,” 10.11.1941.
} 
yüksek duygulara tâbi olmalarını temin eder." ${ }^{22}$ diyerek, millî birlik ve beraberlik konusundaki önemine değindiği güzel sanatlara ilgi gösterilmesi konusunda yetkilileri ve Türkiye Büyük Millet Meclisi'ni göreve çağırmıştır. ${ }^{23}$

Atatürk'e göre sanat güzelliğin ifadesidir. ${ }^{24}$ Musiki, resim, heykeltıraşlık, edebiyat, mimarlık ve danstan oluşan güzel sanatları incelik ve hünerle icra edebilmek, bu anlamda ince bir kabiliyete sahip olmak "sanatkârlık" olarak ifadesini bulur. Atatürk, bu konu üzerinde idarecilerin olduğu kadar Türk çocuklarının da esaslı bir şekilde durmasını istemiştir. ${ }^{25}$

Atatürk, sanatın yaratıcısı ve taşıyıcısı sıfatıyla sanatçılara da büyük değer vermiştir. Çünkü sanatkârlık doğuştan gelen, Allah vergisi bir özelliktir. Sanatçının yaratıcı özeliğinin kaynağını en yüce duygulardan biri olan sevgi teşkil eder. ${ }^{26}$ Sanatçılar toplumu yüksek ideallere ulaştıran insanlardır. Toplumun aynası olmaları nedeniyle bir milletin gelişim sürecini sanatçıları takip ederek anlamak mümkündür. Bu anlamda sanatçılar zor ama önemli görevler üstlenmişlerdir. Bir temsil sonrasında elini öpmek isteyen tiyatro sanatçılarına vefa duyguları ile söylediği: "Sanatkâr el öpmez; sanatkârın eli öpülür." 27 sözleri, Atatürk'ün sanatç1lara verdiği değerin önemli bir kanıtını teşkil etmiştir.

$\mathrm{Bu}$ tespit ve tayinlerden sonra, Atatürk'ün güzel sanatların çeşitli dalları ile ilgili bazı söylemleri ve çalışmaları üzerinde ayrıntıları ile durabiliriz.

\section{Atatürk ve Musiki}

Güzel sanatlar içinde musikinin Atatürk'ün gözünde özel bir yeri vardır. ${ }^{28}$ Atatürk musikiyi Türk İnkılâbı'nın en önemli unsurlarından biri

\footnotetext{
${ }^{22}$ Dünya Gazetesi, Hasan Cemil Çambel, 30.08 .1952

${ }^{23}$ Atatürk'ün Söylev ve Demeçleri, C.I, s.405.

${ }^{24}$ Atatürk'ün Fikir ve Düşünceleri, (Yay.haz.: Utkan Kocatürk), Atatürk Araştırma Merkezi yayınları, Ankara, 1999, s.152.

${ }^{25}$ Cumhuriyet Gazetesi, Cevat Abbas Gürer, "Montrö Imzalandığ Akşam Atatürk Bu Sulh Zaferini Florya'da Nasıl Kutlamıştı?,” 10.11.1941.

${ }^{26}$ Latife Öztoprak, a.g.m., s.733.

${ }^{27}$ Kocatürk, a.g.e., s.153 ve 155 .

${ }^{28}$ Sadi Irmak bu konuyla ilgili bir anısını şu şekilde anlatmıştır: Bir sohbet anında Atatürk yanındaki arkadaşlarına "En güç devrim nedir?" diye sorar. İçlerinden bazıları, bütün devrimlerin birbirinden güç olduğunu ifade ederler. Söz sırası Sadi Irmak’a gelince, o da cevap olarak en güç devrimin lâiklik olduğunu savunur. Nihayetinde Atatürk bu cevapların hiç birisini beğenmez ve yanındakileri bir süre tereddütte bıraktıktan sonra: "En güç devrim, musiki devrimidir. Cünkü; musiki devrimi șahsa önce kendi iç dünyasını unutturmayl, sonra da yeni bir âleme yönelmeyi gerektirir. Onun için çok zordur." der ve konuşmasını: "Çok zor ama yapılacaktır." sözleriyle sonlandırır (Sadi Irmak, Atatürk’ten Anılar, Ankara, 1978, s.17-18).
} 
olarak görmüştür. Nitekim O'na göre, ink1lâp hareketinde en çabuk ve en önde götürülmesi gerekli olan sanat dalı musikidir. Bir milletin musikideki değişikliği algılayıp kavrayabilmesi, inkılâbın toplumda yarattığ 1 değişimin başarısına bir ölçü teşkil eder. ${ }^{29} \mathrm{Bu}$ anlamıyla musikide katedilen mesafe ve ulaş1lan nokta, bir milletin gelişmişlik seviyesini gösterir. ${ }^{30}$

1925 ’te ziyaret ettiği İzmir Kız Öğretmen Okulu'nda öğrencilerle bir araya gelen Atatürk, hayat ile musiki arasındaki ilişkiye yönelik bir soru üzerine; hayatın neşesi, ruhu, sevinci anlamına gelen musikinin hayatın kendisi olduğunu ve musikisiz bir hayatın düşünülemeyeceğini belirterek ${ }^{31}$ bu konu ile ilgili düşüncelerini açık bir şekilde ifade etmiştir.

Atatürk, Osmanlı musikisinin Türkiye Cumhuriyeti'nin inkılâp hareketini temsil edecek kudrette olmadığını düşünmektedir. ${ }^{32}$ Bu musikinin Türk insanının ruhunu ve hislerini tatmin etmeye yetmeyeceği yönündeki kanaatini Sarayburnu'nda Doğu sanatını temsil eden iki musiki topluluğunu dinleme firsatı bulduğunda dile getirmiştir. Bu bağlamda, yaratılış olarak şen ve neşeli bir karaktere sahip olan Türklerin, musikide de tercihlerini mizaçlarına uygun olarak çağdaş musiki yönünde kullanmaları bir gereklilik arz etmiştir. $^{33}$

Klasik Osmanlı musikisi ile Batı musikisini karşılaştıranlara karşı düşündüklerini Ulus gazetesi yazarı B. Kemal Ünal'a aktaran Atatürk, söz konusu söyleşide eski musiki tarzının eksikliklerine değinmiş ve: "inkılâp içinde Türk düşüncesinin basit oyunlara eşlik edecek, insanlarda basit ve geçici heyecanlar uyandıracak bir musiki aramadiğını; aksine yüksek duyguların, hayat ve hatıraların ifadesini sağlayan bir musikinin arayışı içinde olduğunu" bildirerek klasik Osmanlı musikisini diriltmeye çalışmanın çağdaş Türk musikisine bir fayda sağlamayacağını vurgulamak istemiştir. ${ }^{34}$

Atatürk, yetiştiği çevrenin etkisi ve geçmişten gelen bir alışkanlık neticesinde alaturka musikiden hoşlanmasına rağmen, Batı musikisine uzak durmamıştır. $\mathrm{Bu}$ konuyla ilgili olarak Falih Rıfkı Atay, Atatürk'ün:

\footnotetext{
${ }^{29}$ Ayın Tarihi, S.12, 1934, s.23. Atatürk'ün Söylev ve Demeçleri, C.I, s.396. Bu konuda Atatürk, ünlü Fransız düşünür Montesquieu'nün “Bir milletin musikideki meyline ehemmiyet verilmezse, o milleti ilerletmeniz mümkün olamaz." sözünden çok etkilenmiş ve musiki ile ilgilenmesinin bir sebebini de bu düşünceye bağlamıştır (Kemal Arıburnu, Atatürk’ten Anılar, İnkılâp yayınevi, İstanbul, 1998, s.247).

${ }^{30}$ Cumhuriyet Gazetesi, "Atatürk'ün 2 Eylül 1936'da Balkan Festivali'nde Kâzım Dirik'e ve Bir Türk Çocuğuna Yazdırtıp Okuttuğu Notlar”, 05.09.1936.

${ }^{31}$ Atatürk'ün Söylev ve Demeçleri, C.II, s.231-232.

${ }^{32}$ Atatürk'ün Söylev ve Demeçleri, C.I, s.396.

${ }^{33}$ Atatürk'ün Söylev ve Demeçleri, C.II, s.273.

${ }^{34}$ Ulus Gazetesi, B.Kemal Ünal, "Musikiye Ait Bir Not", 10.11.1939.
} 
"Çocuklarımızın ve gelecek nesillerin musikisi, Batı medeniyetinin musikisidir." söylemini çeşitli vesilelerle dile getirdiğini belirtmiştir. ${ }^{35}$ Alman biyografya yazarı Emil Ludwig, 1930 Martı'nda Atatürk ile yaptığ bir söyleşide; Doğu musikisinin Batılı kulaklara garip geldiğini, bir Batılı için Doğu musikisinin anlaşılamaz olduğunu öne sürünce Atatürk bu tenkide: "Bunlar hep Bizans'tan kalma şeylerdir. Bizim gerçek musikimiz Anadolu halkından işitilebilir." şeklinde bir açılama getirmiştir. Batı musikisinin çağdaş seviyeye 400 yıl kadar bir sürede ulaştığını öğrenen Atatürk: "Bizim bu kadar beklemeye vaktimiz yok. Bunun için Batı

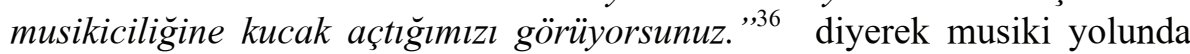
kaynağını Anadolu'dan alan hızlı bir değiş̧imin gerekliliğine işaret etmiştir.

Atatürk'ün Batı musikisine yönelişi Emil Ludwig'e verdiği cevaptan da anlaşılacağ1 üzere özgün değerleri içinde barındıran, ancak Batı'da yüzyıllardır işlenegelmiş çoksesli musiki çalışmalarından ve tecrübelerinden de istifade etmeyi amaçlayan bir yöneliştir. ${ }^{37} \mathrm{Bu}$ yüzden, Batı musikisine kucak açmak ve bu musikiyi öğrenmek Türk musikisinden uzaklaşmak anlamına gelmemektedir. ${ }^{38}$ Atatürk, hem Türk hem de Batı musikisini yüksek medeniyetlerin ürünü olarak telakki etmiştir. Bunun için çağdaş musikiye giden yolun geleneksel Türk musikisinden geçmesi gerektiğine inanmıştır. Esas mesele Türk musikisinin Batı'da saygıyla dinlenecek bir şekle sokulmasıdır. ${ }^{39}$ Bunun için millî, ince duyguları, düşünceleri anlatan deyişleri, söyleyişleri toplamak ve onları en son musiki kurallarına göre işlemek gerektiğine, Türk musikisinin ancak bu şekilde gelişip, evrensel musiki içinde yer bulabileceğine işaret etmiştir. ${ }^{40}$ Netice itibariyle Atatürk'e göre Türk milleti için gerekli olan musiki tarzının, özünü halk musikisinden alan çok sesli bir musiki olduğunu açıkça söyleyebiliriz. ${ }^{41}$

\footnotetext{
${ }^{35}$ Falih Rifkı Atay, Çankaya, İstanbul, 1998, s.410. Atatürk'ün buna benzer bir söylemi de Kâzım Özalp tarafindan nakledilmektedir. Atatürk, Özalp'e "Bizler alaturka musikiye alışmışız; ama yeni nesiller alafranga musikiye alışmalıdırlar."demiştir (Milliyet Gazetesi, Kâzım Özalp, “Özalp Atatürk'ü Anlattyor”, 27.11.1969).

${ }^{36}$ Ayın Tarihi, 1930, C.22, S.73, s.6054-6055. Ayrıca bkz.; Enver Ziya Karal, Atatürk’ten Düșünceler, ODTÜ Geliștirme Vakfi Yayıncılık ve İletișim A.Ș., Ankara, 1998, s.77.

37 Günay Günaydın, "Atatürk ve Müzik", Uluslar arası Atatürk ve Güzel Sanatlar Sempozyumu Bildirileri (26-27 Ekim 2001/Ankara), Yay.haz.: Nail Tan ve Hayrettin İvgin, Cumhuriyet, Kültür ve Tanıtma Vakfı yayınları, Ankara, 2005, s.69.

${ }^{38}$ Kazım Özalp, Atatürk’ten Anılar, Türkiye İş Bankası yayınları, Ankara, 1994, s.88-89.

${ }^{39}$ Mesut Cemil Anlatıyor: Nükte, Fıkra ve Çizgilerle Atatürk II, Derleyen: N.A. Banoğlu, 1954, s.52.

${ }^{40}$ Ayın Tarihi, 1934, S.12, s.23. Atatürk'ün Söylev ve Demeçleri, C.I, s.396.

${ }^{41}$ Adnan Saygun, Atatürk ve Musiki, O'nunla Birlikte O'ndan Sonra, Sevda-Cenap And Müzik yayınları, Ankara, 1934, s.48-49. Atatürk, 1927'de İstanbul'a gelmiş, bu sırada musiki eğitimi için İstanbul'da bulunan ve aynı zamanda bir radyoda halk musikisi çalışmaları yapan
} 
$\mathrm{Bu}$ duygu ve düşünceler içinde Atatürk yeni şairlerden, ediplerden, musiki bilginlerinden ve özellikle ses sanatçılarından beklentilerini şu şekilde dile getirmiştir:

"Biz, bir Türk bestesini dinlediğimiz zaman ondan geçmişin uyanma bırakması lâzım gelen hikâyesini kalbimize giren oklar gibi duymak isteriz. Acl olsun, tatlı olsun biz, bir beste dinlerken ve farkinda olmaksızın hislerimizin incelir olduğunu duymak isteriz. Bütün bunlardan başka musikiden beklediğimizin maddî, fikrî ve hissî uyanıklık ve çevikliğin takviyesi olduğuna şüphe yoktur. ",42

$\mathrm{Bu}$ söylemden anlaşılacağı üzere, Atatürk sanatçılardan geçmişle anlamlı bir bağ kuran ve geleceğe dair yeni umutlar aşllayan bir musiki beklentisi içindedir.

Atatürk'ün çağdaş musiki yolundaki ilk çalışması, Sultan 2. Mahmut döneminde (1808-1839) teşkil edilen Muzıka-y1 Hümâyûn'un ${ }^{43}$ Saray Orkestrası'n1 1924'te İstanbul'dan Ankara'ya getirterek, "Riyâset-i Cumhur Musiki Hey'eti” adıyla bugünkü “Cumhurbaşkanlığı Senfoni Orkestrası”nı

Sadi Yaver Ataman'1 bir vesileyle dinleme firsatı bulmuştur. Ataman, birkaç parça çaldıktan sonra Atatürk ondan sazı kendisine vermesini istemiş ve sazın tellerine bir iki dokunduktan sonra: "Genç arkadaşıma teşekkür ederim, bize Anadolu'nun güzel havasını getirdi. Beyler, bu bir Türk sazıdır. Bu küçük sazın bağrında bir milletin kültürü dile geliyor. Milletimizin kültür ve sanat hareketlerini ve seviyesini, millî geleneklere bağll kalarak, medenî dünyaya ayak uydurmaya mecbur olduğumuzu unutmamalıyı, bunu bu vesile ile de söylemekten memnunum. Bu küçük sazın bağrından kopan nă̆meleri, bu istikâmette geliştirmeye ve değerlendirmeye klymet ve ehemmiyet verilmelidir." demiştir Sadi Yaver Ataman, Atatürk ve Türk Musikisi, Kültür Bakanlığı yayınları, Ankara, 1991, s.7-13. Ünlü ses sanatçısı Safiye Ayla da Atatürk'ün İstanbul'da kaldığı günlerde özellikle dinlemek istediği sanatçılar arasında yer almış ve sıklıkla Dolmabahçe Sarayı'na davet edilmiştir. Atatürk özellikle "Alişimin kaşları kare”, "Köşküm var deryaya karşı", "Maya dă̆dan kalkan kazlar" gibi Rumeli türkülerini Safiye Ayla'dan dinlemekten büyük bir mutluluk duymaktaydı Refik Ünal, Atatürk'ün Sevdiği Türküler, Ankara, 1973, s.23.

${ }_{42}$ Ulus Gazetesi, B. Kemal Ünal, "Musikiye Ait Bir Not", 10.11.1939.

${ }^{43}$ Osmanlı Devleti'nde, Batılılaşma hareketlerinin etkisiyle Sultan 2. Mahmut (1808-1839), Avusturya-Macaristan İmparatorluk Saray1'ndan ünlü besteci “Gaetano Donizeeti”yi ve orkestra şefi olan kardeşi “Giuseppe” ”i ülkeye davet etmiştir. Bu müzisyenler Enderun'dan seçtikleri ve yetiştirdikleri öğrencilerle "Muzıka-yı Hümâyûn” kurmuşlardır. Önceleri yalnız marşlar, opera uvertürleri ve potpuriler çalmakla görevli olan ve bando karakteri taşıyan bu topluluk, Sultan Abdülmecit (1839-1861) devrinde "Makam-ı Hilâfet Muzıkası" adı ile senfonik orkestra kadrosuna dönüştürülmüş ve Sultan Vahdettin zamanına kadar "Ístanbul Saray Orkestrası" ve "Deniz Bandosu" olarak iki topluluk şeklinde çalışmalarına devam etmiştir. Cevat Memduh Artar ve diğerleri, Atatürk Türkiyesi’nde Müzik Reformu Yılları, Kolektif eser, Flarmoni Derneği yayınları, İstanbul, 1982, s.69. 
kurdurmak olmuştur. ${ }^{44}$ Söz konusu tarihten itibaren bazı gençler musiki eğitimi almak üzere Avrupa'ya gönderilmişlerdir. ${ }^{45} \mathrm{Bu}$ faaliyetleri çağdaş musikiyi yurda sokmak amaciyla Ankara'da "Musiki Muallim Mektebi"nin açı1ışı takip etmiştir. Bu okulda hem Türk musikisi hem de Batı musikisi eğitimi yapılmıştır.

Atatürk'ün direktifleri ve Bakan Yusuf Hikmet Bayur'un çalışmaları ile 1936'da açılan "Millî Musiki ve Temsil Akademisi” yurtta bilimsel esaslarla millî musikiyi işlemek, yükseltmek ve musikinin yanı sıra sahne sanatlarının diğer dalların da bilgili elemanlar ve öğretmenler yetiştirmek amacıyla eğitim hayatına başlamıştır. Zamanla hâsıl olan ihtiyaç nedeniyle orkestra elemanlarının da yetiştirildiği bu sanat yuvasında Türk İstiklâl Marşı'nın bestecisi Osman Zeki (Üngör) Bey gibi idealist müzisyenler çalışmaya başlamıştır. ${ }^{46}$ Ardından ünlü halk musikisi araştırmacısı Macar Besteci Béla Bartok, ${ }^{47}$ Alman Besteci Paul Hindemith ${ }^{48}$ ve tiyatro, opera, bale alanlarında kariyer sahibi Carl Ebert ${ }^{49}$ gibi yabancı uzmanlar Türk musikisi hakkında

\footnotetext{
${ }^{44}$ Erdem Yücel, “Atatürk ve Güzel Sanatlar”, Türk Dünyası Tarih Dergisi, C.3, S.32, İstanbul, 1989, s.55.

${ }^{45}$ Avrupa'ya musiki eğitimi almak için gönderilen bu gençler arasında Ekrem Zeki Ün, Ulvi Cemâl Erkin, Necil Kâzım Akses, Ferit Alnar ve Ahmet Adnan Saygun gibi Türk musikisinde önemli yerler işgal eden müzisyenler vardır. $\mathrm{Bu}$ müzisyenler, yine eğitimini Avrupa'da tamamlayıp Dârü'l-Elhân'da musiki öğretmenliği yapmakta olan Cemâl Reşit Rey ile beraber Cumhuriyet döneminin ilk besteci kuşağını oluşturmuşlardır Gülper Refiğ, "Atatürk Dönemi Musiki Devrimi”, Atatürk ve Sanat Sempozyumu, (26-28 Ekim 1981), İstanbul Güzel Sanatlar Akademisi yayın no:86, İstanbul, 1983, s.125.

${ }^{46}$ Aslan Tufan Yazman, "Atatürk ve Güzel Sanatlar”, Sanat Dünyamız, C.8, S.22, (Özel say1), İstanbul, 1981, s.30.

47 Türk Hükûmeti'nin daveti üzerine 1936 Kasımı'nda Ankara'ya gelen Béla Bartok, verdiği konferans ve konserlerle büyük ilgi toplamıștır. Türk bestecilerine kaynak teșkil etmek üzere Halk musikisi derleme ve "Halk Musikisi Arşivi" oluşturma çalışmalarına ağırlık vermiştir. $\mathrm{Bu}$ amaçla 1937-1952 yılları arasında Anadolu'da derleme gezileri yapılarak, zengin bir folklor malzemesinin toplanmasında öncü rol oynayan uzmanlardan biri olmuştur Abdurrahman Çayc1, Gazi Mustafa Kemal Atatürk, Ankara, 2002, s.473.

${ }^{48}$ Alman Profesör Paul Hindemith, Türkiye'de bir "Musiki Konservatuarl” oluşturmak ve musiki kültürünün organizasyonu işlerinde Maarif Vekâleti Hars (Kültür) Dairesi'ne danışmanlık yapmak üzere 1935-1938 yılları arasında Türkiye'de bulunmuştur. Oluşturulacak olan konservatuarın amacını, yönetimini, ilkelerini, ders programlarını, sınav yönetmeliğini kapsayan ve "Türk Musiki Hayatını Kurtarmak Iç̧in Teklifler" adını taşıyan kapsamlı bir rapor hazırlayarak Maarif Vekâleti'ne sunmuştur. Musiki Muallim Mektebi için de birtakım önerilerde bulunan Hindemith, buraya yeni ögretim elemanları kazandırmıştır. Bunun yanı sıra Gazi Terbiye Enstitüsü’nde açılan “Musiki Bölümü”nün kuruluş çalışmalarına da iştirak etmiştir Çayc1, a.g.e., s.473.

49 Alman tiyatro ve opera yönetmeni Carl Ebert, Atatürk'ün isteği üzerine 1936'da “Cumhurbaşkanlı̆̆ı Filarmoni Orkestra"nın konuğu olarak Türkiye’ye gelmiştir. Ankara'da Devlet Konservatuarı ile Devlet Tiyatrosu'nun kuruluşunda büyük hizmetleri olmuştur. 19361947 y1lları arasında "Devlet Tiyatrosu Tatbikat Sahnesi" ile "Opera Stüdyosu”nun
} 
görüşlerinden yararlanılmak üzere Ankara'ya davet edilmişlerdir. ${ }^{50} \mathrm{Bu}$ uzmanlar çağdaş Türk musikisinin oluşmasında önemli katkılar sağlamışlardır. Millî Musiki ve Temsil Akademisi, 1940’tan itibaren “Devlet Konservatuart" adıyla eğitim hayatına devam etmiştir.

Cumhuriyet Türkiyesi'nin musiki kültürünün halk musikisinden kaynaklanması gerektiğini düşünen Atatürk, Birinci Dünya Savaşı yıllarında musiki eğitimi amaciyla İstanbul'da kurulan "Dârü'l-Elhân",51 da görev yapan Türk musikisi bilgini Rauf Yekta Bey'in öncülügünde Türk halk musikisi araştırmalarını ve Dârü'l-Elhân'ın genç musiki hocalarından Cemâl Reşit (Rey) Bey'in halk türkülerini çok sesli hâle getirme denemelerini teşvik etmiştir. Daha sonra orkestra eserlerini Paris'te sergileme firsatı bulan bu sanatçılar Türk musikisinin çağdaşlaşması yolunda önemli rol oynamışlardır. $^{52}$

1925'te Maarif Vekâleti Hars Dairesi Müdürü Hâmit Zübeyr Koşay'ın nezaretinde musiki öğretmenleri Seyfeddin ve Mehmet Sezai Asaf (Asal) kardeşler, Anadolu'da halk musikisi derleme çalışmalarına başlamışlar ve ilk aşamada elde edilen 80 halk ezgisi "Yurdumuzun Nağmeleri" adiyla yayımlanmıştır. ${ }^{53}$ Söz konusu derleme çalışmaları belli bir program dâhilinde devam etmiş, bu sırada Muzaffer Sarısözen, Ahmet Kutsi Tecer, Tahsin Banguoğlu, Ahmet Adnan Saygun ve Sadi Yaver Ataman gibi önemli sanatçılar birçok halk musikisini derlemişler ve halk kültürü çalışmalarına yeni bir ivme kazandırmışlardır. $\mathrm{Bu}$ dönemde halk musikisinin tespit edilebilen önemli kaynak kişileri arasında Atatürk'ün "Şark Bülbülü" lakabını verdiği Celâl Güzelses, Malatyalı Fahri Kayahan, Urfalı Cemil Cankat, Muharrem Ertaş, Refik Başaran, Aşık Veysel Şatıroğlu gibi önemli isimler vardır. $^{54}$

yönetmenliğini yapmıştır Özdemir Nutku, “Cumhuriyet Döneminde Türk Tiyatrosunu Geliştiren İlk Adımlar”, Atatürk ve Sanat Sempozyumu, (26-28 Ekim 1981), İstanbul Güzel Sanatlar Akademisi no:86, İstanbul, 1983, s.111.

${ }^{50}$ Yazman, a.g.m., s.30.

${ }^{51}$ Dârü'l-Elhân, 1916'da Maarif Encümeni'ne bağlı olarak kurulmuş, Türk ve Batı musikisi eğitimlerini birlikte sürdüren bir musiki eğitim kurumu idi. 1926'da İstanbul Belediye Konservatuarı hâline getirilmiştir Refiğ, a.g.m., s.123 ve 125 .

${ }^{52}$ Refiğ, a.g.m., s. 125.

${ }^{53}$ Nail Tan, "Atatürk Döneminde Plânlı İlk Resmî Halk Müziği Derlemesi ve 'Yurdumuzun Nağmeleri' Kitabı”, Uluslararası Atatürk ve Güzel Sanatlar Sempozyumu Bildirileri (2627 Ekim 2001/Ankara), Yay.haz.: Nail Tan ve Hayrettin İvgin, Cumhuriyet, Kültür ve Tanıtma Vakfi yayınları, Ankara, 2005, s.142-143.

${ }^{54}$ Armağan Elçi, "Atatürk Dönemi Belli Başlı Halk Müziği Araştırmacıları, Sanatçıları ve Kaynak Kişileri”, Uluslararası Atatürk ve Güzel Sanatlar Sempozyumu Bildirileri (26-27 Ekim 2001/Ankara), Yay.haz.: Nail Tan ve Hayrettin İvgin, Cumhuriyet, Kültür ve Tanıtma Vakfi yayınları, Ankara, 2005, s.34 vd. 
Bütün bu çalışmalardan anlaşıldığı üzere, Atatürk Türkiye'deki musiki politikasıyla çok yakından ilgilenmiştir. Musiki eğitim kurumlarının açılması, sanatçıların teşviki, Türk musikisinin senfonik orkestra ile çalınabilir biçimlere sokulması, bir sonraki başlık altında değerlendireceğimiz üzere sahne için musikili Türk eserlerinin yaratılması ve bunların sonucu olarak Türk milletinin dinamizmine yaraşır, çağdaş ve millî bir musikinin oluşturulması Atatürk'ün bu konudaki düşüncelerinin ve çalışmalarının özünü teşkil etmiştir. ${ }^{55}$

\section{Atatürk ve Opera, Bale}

Türkiye'de ilk ciddi ve düzenli opera çalışmaları Atatürk'ün istek ve desteği ile Cumhuriyet döneminde başlamıştır. ${ }^{56}$ Tamamen öz kaynaklara dayanan bir operanın kurulması Atatürk'ün güzel sanatlar alanındaki en büyük isteklerinden birini teşkil etmiştir. ${ }^{57} 1934$ 'te Cumhurbaşkanlığ 1 Senfoni Orkestrası Şefliği'ne getirilen Ahmet Adnan Saygun, Atatürk'ün telkin ve teșvikiyle "Özsoy" ve "Taşbebek" adlı ilk Türk operalarını bestelemiştir. $^{58} 1936$ 'da konservatuar kurma hazırlıklarını takiben bir "Temsil Şubesi” oluşturmak ve bunun müfredatını tespit etmek üzere Alman

\footnotetext{
55 Atatürk'ün Türk musikisinin icrası ve çağdaş anlayışla işlenmesi konusundaki görüşlerini yanlış anlayan bazı idarecilerin etkisiyle 1934-1936 yıllarında Türk musikisinin radyolarda yasaklanması söz konusu olmuştur. Ancak bu sorun, Atatürk'ün görüş ve önerileri doğrultusunda derhâl ortadan kaldırılmıştır Güla Coşkun, "Günümüz Türkiyesinde Müzik", Türkiye'de Sanatın Bugünü ve Yarını, Hacettepe Üniversitesi Güzel Sanatlar Fakültesi I. Ulusal Sanat Sempozyumu, Güzel Sanatlar Fakültesi yayınları no:1, Ankara, 1985, s.127. Sadi Yaver Ataman, "Milletlerarası Folklor Kongresi ve Bir Bildiri Münasebetiyle”, Türk Folkloru, C.3, S.25, 1981, s.13-14. Arıburnu, a.g.e., s.243-246.

56 Cevat Memduh Altar ve diğerleri, Atatürk Türkiyesi'nde Müzik Reformu Yılları, Flarmoni Derneği yayınları, İstanbul, 1982, s.94.

${ }^{57}$ Melâhat Özgü, Atatürk'ün Edebiyat ve Sanat Anlayışı, Türk Tarih Kurumu Basımevi, Atatürk Konferansları'ndan ayrı basım, Ankara, 1964, s.52. Bu konuyla ilgili şu anı oldukça önemlidir: Atatürk, Sofya'da ataşemiliterken yanında bulunan arkadaşı Şakir Zümre ile beraber bir akşam "Carmen" adlı bir operayı dinleme firsatı bulmuştur. Otele döndükten sonra kendisini bir türlü uyku tutmamış ve Şakir Zümre'nin odasına giderek: "Şakir, Balkan Savaşı'nı yitirişimizin nedenlerinden birini daha bu akşam anladım. Biz, Bulgarları Çoban bilirdik. Bak, biz farkına varmadan, onlar nasıl ilerlemişler. Balesi Bulgar, şefleri Bulgar...Biz, bu uygarlık düzeyine ulaşamazsak, bize yaşam hakkı yok..." diyerek duygularını, düşüncelerini ve duyduğu heyecanı anlatmıştır Perihan Çambel, Atatürk, Evrim, Devrim ve Müzik, IX. Türk Tarih Kongresi'nden ayrı basım, TTK yayını, Ankara, 1989, s. 1984.

${ }^{58}$ Refiğ, a.g.m., s.126. İran Şahı Rıza Pehlevi'nin Türkiye’yi ziyareti vesilesiyle Atatürk, opera tarzında orjinal bir Türk eserinin sahneye konmasını düşünmüş ve bu işi besteci Ahmet Adnan Saygun'a havale etmişti. Adnan Saygun'un "Özsoy” adlı ilk küçük operası böylece ortaya çıkmıştır. Atatürk, çağdaş sanat anlayışıyla bestelenen bu ilk Türk operasının misafirinin üzerinde bıraktığı güzel etkiyi görmekten son derece mutluluk duymuştur (Ârif Kaptan, "Atatürk ve Sanat”, Türk Dili Dergisi, C.V, S.50, 1955, s.78.
} 
tiyatro sanatçısı ve bilim adamı Prof. Carl Ebert, Türk Hükûmeti tarafindan davet edilmiştir. Netice itibariyle Devlet Konservatuarı'nda tiyatro ve opera bölümlerinin kurulması, ${ }^{59}$ ders programlarının hazırlanması ve operaya bağlı bale sınıflarının oluşturulması konusunda bu bilim adamından yararlanılmıştır. ${ }^{60}$

1936'da Ankara'da aç1lan "Millî Musiki ve Temsil Akademisi" içinde ilk baştan itibaren programa alınan "Bale Bölümü" ise arzu edilen gelişmeyi 1948 'de Devlet Konservatuarı içinde "Devlet Bale Okulu” "nun açılması ile gösterebilmiştir. Türk Hükûmeti 1947'de İngiliz Kraliyet Balesi'nin kurucusu ve çağdaş balenin en önemli isimlerinden biri olan "Dame Ninette de Valois" $i$ görüşlerinden yararlanmak üzere Türkiye'ye davet etmiştir. Söz konusu sanatçının görüş ve önerileri doğrultusunda Türkiye'de bale sanatının temeli atılmıştır. ${ }^{61}$ Devlet Konservatuarı mezunları ileriki yıllarda "Türk Devlet Tiyatrosu" ve "Devlet Opera ve Balesi"nin açılışında önemli bir etkiye sahip olmuşlardır. ${ }^{62}$ Bu gelişim çizgisi içinde Türkiye'de ilk bale gösterileri bale öğretmenleri Travis Kemp ve eşi Molly Lake'in gözetiminde 1960 'da sahnelenmiştir. ${ }^{63}$

Opera ve bale sanatlarında görülen söz konusu gelişmelerin ana kaynağını hiç şüphe yok ki Atatürk'ün çağdaşlaşma anlayışı teşkil etmiştir. Girişilen çok yönlü çağdaşlaşma programı içinde Türkiye'nin bale sanatını benimseyen ilk Müslüman ülke olması da vurgulamakta fayda gördüğümüz, dikkate değer bir özelliktir. ${ }^{64}$

\section{Atatürk ve Tiyatro}

Sanatın toplum hayatına yansıyan en canlı örneklerinden biri de tiyatrodur. Anadolu'da halk tiyatrosu adını verebileceğimiz kukla, karagöz ve ortaoyunu gibi sanat etkinlikleri yüzyıllar boyu halkın duygu ve

\footnotetext{
${ }^{59}$ Nutku, a.g.m., s.111. Türkiye'de tiyatro ve operayı bünyesinde toplayan “Devlet Tiyatrosu Genel Müdürlüğ̈̈’nün 10 Haziran 1949'da kurulmasiyla birlikte bale sanatı da bu genel müdürlüğün çalışma alanına alınmıştır. Opera ve bale sanatlarının kısa sürede büyük bir gelişme göstermesi nedeniyle 13 Temmuz 1970'te "Opera ve Bale Genel Müdürlüğü" kurulmuştur Yalçın ve diğerleri, a.g.e., s.212.

${ }^{60}$ Şerafettin Turan, Türk Devrim Tarihi, 4. Kitap, Birinci Bölüm, Ankara, 1999, s.65. Carl Ebert, Türkiye'de Türk sanatçıları ile Türkçe olarak ilk belli başlı opera gösterisini Ankara Halkevi'nde 21 Haziran 1940'ta sunabilmiştir. Sunulan eser, Mozart'ın "Bastien und Bastienne" adlı 1 perdelik operasıdır. Bu gösteriyi "Madam Butterfly" adlı operanın ikinci perdesinin sunumu takip etmiştir Cevat Memduh Altar ve diğerleri, a.g.e., s.95.

${ }^{61}$ Cevat Memduh Altar ve diğerleri, a.g.e. s.99-100.

${ }^{62}$ Giritli, a.g.e., s.22.

${ }^{63}$ Yazman, a.g.m., s.31.

${ }^{64}$ Şebnem Aksan, "Atatürk Türkiyesi’nde Bale", Atatürk ve Sanat Sempozyumu, (26-28 Ekim 1981), İstanbul Güzel Sanatlar Akademisi yayın no:86, İstanbul, 1983, s.119.
} 
düşüncelerine tercüman olmuştur. Batılı anlamda bir tiyatro sanatının Türk topraklarında ortaya çıkışı ise Tanzimat döneminde vuku bulmuştur. Sultan Abdülmecit (1839-1861) ile II. Abdülhamit (1876-1909)'in tiyatroya özel ilgi duyduğu bilinmektedir. Ancak Osmanlı Devleti'nin son döneminde yaşanan siyasi gerginlikler ve Türk kadının sahneye çıkmasının Osmanlı toplumunda hoş karşılanmaması gibi yapısal sorunlar çağdaş anlamda bir tiyatronun Türk topraklarında gelişmesine sekte vurmuştur. ${ }^{65} \mathrm{Bu}$ nedenle tiyatro sanatı Cumhuriyet dönemine kadar hızlı bir gelişim gösterememiştir. Atatürk'ün kurduğu Cumhuriyet, toplumu çağdaş gelişmelerden geri bırakan bu etkileri bertaraf ederek, sanatın ve sanatçının yolunu açarak bu konudaki inisiyatifi devralmıştır.

Atatürk döneminde tiyatro sanat1, biri Muhsin Ertuğrul'un yönlendirdiği "Dârü'l-Bedâyi (Şehir Tiyatrosu)" "66 ve diğeri çağdaş usullerle gelişimini sürdüren Devlet Konservatuarı'nın "Tiyatro Bölümü” olmak üzere iki ayrı hayat suyundan beslenmiştir. ${ }^{67}$

Temelleri 1914'te atılan Dârü'l-Bedâyi, 1926'dan itibaren yeni ve sistemli bir çalışma programı benimsemiştir. Söz konusu tarihte, Maarif Vekâleti'ne bağlı olarak "Sanâyi'-i Nefîse Müdürlüğü" ile "Sanâyi'-i Nefìse Encümeni" nin kurulmas1, güzel sanatların korunmas1 ve gelişmesi yolunda önemli bir aşama olmuştur. Nitekim Sanâyi'-i Nefîse Encümeni'nin önayak olmasıyla çıkarılan 25 Haziran 1927 tarihli yasa ile: "Maarif Vekâletince terbiyevî mahiyette sayllacak müesseselerin verecekleri konserler ve temsillerden istihlâk (tüketim) vergisi alınmaması" kabul edilmiştir. Dârü’lBedâyi, söz konusu teşvikler ile bu yıllarda ilk büyük ve başarılı ürünlerini vermeye başlamıştır. ${ }^{68}$

Dârü'l-Bedâyi sanatçıları 1930 Nisanı'nda yeni Türk Ocağı Tiyatrosu'nu açmak üzere Ankara'ya gelmişler ve burada "Hamlet", "Murâ̂", "Muhayyel Hasta" gibi klasiklerle Alman ve Fransız modern piyeslerinden bazılarını sergilemişlerdir. Bu oyunları izleyen Atatürk, Muhsin Ertuğrul başta olmak üzere söz konusu oyunlarda emeği geçen bütün sanatçıları Çankaya Köşkü’ne davet etmiş ve önce sanatçılara daha sonra da diğer davetlilere yönelerek şunları söylemiştir:

\footnotetext{
${ }^{65}$ Özgü, a.g.m., s.53.

${ }^{66}$ Devlet Tiyatrosu niteliğinde olmak üzere tiyatro ve musiki bölümlerinden oluşan Dârü’lBedâyi Meşrutiyet döneminde kurulmuş, 1934'e kadar Türk tiyatrosunun en önemli kurumu olarak faaliyetine devam etmiștir Durmuş Yalçın ve Diğerleri, Türkiye Cumhuriyeti Tarihi, C.II, Kolektif eser, Atatürk Araştırma Merkezi yayınları, Ankara, 2002, s.210.

${ }^{67}$ Yazman, a.g.e., s.31.

${ }^{68}$ Nutku, a.g.m., s.109.
} 
"Siz benim tâ ateşemiliterlik çağımdan beri memleketimizde görmeyi candan özlediğim bir hayali gerçekleştirdiniz. Böylesine birbirine bağll bir sanat topluluğunu kendi imkânlarınızla hazırlayıp bize getirdiniz, gösterdiniz. Efendiler, hepiniz me'bûs olabilirsiniz, vekil olabilirsiniz, hattâ Reis-i Cumhur olabilirsiniz. Fakat sanatkâr olamazsınız. Hayatlarını büyük bir sanata vakfeden bu çocuklart sevelim." ${ }^{99}$

Atatürk bu sözleriyle sanatçılara verdiği önemi ve değeri gözler önüne sermiş ve sanatçıların toplum hayatındaki öncü rollerine ve özel konumlarına dikkat çekmiştir.

1936'da açılan "Millî Musiki ve Temsil Akademisi” musikiye olduğu kadar diğer sahne sanatlarına da önemli ölçüde fayda sağlamıştır. Söz konusu akademinin "Teşkilât kanunu"nda belirtilen: "Sahne temsilinin her dalında bilgili elemanlar ve öğretmenler yetiştirmek" amac1 doğrultusunda ödenekli bir tiyatro ve opera için önemli bir adım atılmıştır. Akademinin “Tiyatro Bölümü” 1936'da çalışmalara başlayabilmiştir. Akademi 1936'da "Ankara Konservatuarı" adını almıştır. Tiyatro sanatının kendi niteliğine özgü eğitim yuvalarında öğretilmesinin gerekliliği konusunda Darü’l-Bedâyi Müdürü Muhsin Ertuğrul ile Sanatçı Münir Hayri Egeli'nin önerileri, Atatürk'ün söz konusu konservatuarın açılışı konusundaki hassasiyetini artırmıştır. $^{70} \mathrm{Bu}$ konservatuar, çağdaş Türk tiyatrosu için en önemli aşamalardan birini teşkil etmiştir. Takiben Atatürk'ün telkin ve tavsiyeleri ile musikide ve sahnede gerekli teknik elemanların yetiştirilmesi konusunda TBMM'nin hafizası daima taze tutulmuștur." 1940'tan itibaren "Devlet Konservatuarl" olarak görevini sürdüren bu konservatuarda ${ }^{72}$ eğitim vermek üzere Türkiye'ye davet edilen ünlü Alman tiyatro sanatçısı ve bilim adamı Carl Ebert, tiyatro ve opera bölümlerinin kuruluş ilkelerini saptamıştır. Bu durum Türk tiyatrosu için önemli bir gelişim aşamasını teşkil etmiş, $3 \mathrm{k} 1 \mathrm{z}$ ve 5 erkek öğrenci ile öğrenime geçen "Tiyatro bölümü" ilk mezunlarını 1941 'de vermiştir. ${ }^{73}$

Atatürk'e göre; mimariyi, resmi, edebiyatı ve musikiyi içinde barındıran tiyatro güzel sanatların bir sentezi durumundadır. Toplum bu sanat vasıtasıyla sağlam ve hasta yanlarını açık bir şekilde görebilir. ${ }^{74} \mathrm{Bu}$

${ }^{69}$ Cumhuriyet, Muhsin Ertuğrul, “Bir Dönüm Gecesi”, 14.4.1963.

${ }^{70}$ Turgut Özakman, "Türk Tiyatrosu ve Atatürk", Erdem, Ankara, 1988, C.4, s.12. Metin And, Atatürk ve Tiyatro, Devlet Tiyatroları yayınları no:1, Ankara, 1983, s.55-56.

${ }^{71}$ Bkz.; Atatürk'ün Söylev ve Demeçleri, C.I, s.420.

${ }^{72}$ Yalçın ve diğerleri, a.g.e., s.210-211.

${ }^{73}$ Nutku, a.g.m., s.111.

${ }^{74}$ Enver Ziya Karal, “Atatürk ve Sanat”, Devlet Tiyatrosu Dergisi, C.39, Ankara, 1968, s.4. 
düşüncelerle de olsa gerek Atatürk, Afet İnan'ın belirttiği üzere bir tiyatro eseri bile yazmak istemiştir. ${ }^{75}$

Sanata olduğu kadar tarihe de büyük önem veren Atatürk, tiyatro eserlerinde tarihî olaylardan ve bilgilerden yararlanılmasını tasvip etmiştir. ${ }^{76}$ Mesela Faruk Nafiz Çamlıbel'in İstanbul'da sahnelenen "Akın",77 adlı tarihî tiyatro eserini çok beğenen Atatürk, bu eserde rol alan sanatçıları övgüyle yâd etmiş ve gençlerin bu alanda eğitim almaları için Avrupa'ya gönderilmeleri konusunda Hükûmet'i yönlendirmiştir. Yaptığı edebî çalışmaların yanı sıra tiyatro eserleri de kaleme alan Behçet Kemal Çağlar, Atatürk'ün teveccühüne mazhar olmuş bir diğer sanatçıdır. O da söz konusu alanlarda bilgisini arttırmak amacıyla İngiltere'ye gönderilmiştir. Yolculuk öncesinde Atatürk'ün Behçet Kemal Çağlar'a: "İyi tarih bilirsen iyi piyes yazarsın" "78 demesi de tarih ile tiyatro arasındaki bağı gözler önüne sermesi açısından dikkat çekicidir.

\section{Atatürk ve Sinema}

Sinema, 20. yüzyılın başlarından itibaren dünya çapında yaygınlaşan bir sanat dalı olmuştur. Atatürk bu sanat ile de yakından ilgilenmiştir. Engin bir ileri görüşle: "Sinema öyle bir keşiftir ki, bir gün gelecek barutun, elektriğin ve kitaların keş̧inden çok dünya medeniyetinin veçhesini değiştireceği görülecektir. Sinema, dünyanın en uzak köşelerinde oturan insanların birbirlerini sevmesini, tanımalarını temin edecektir. Sinema insanlar arasındaki görüş, düşünüş farklarını silecek, insanlık idealinin tahakkukuna en büyük yardımı yapacaktır. Sinemaya lâyı olduğu ehemmiyeti vermeliyiz. "j9 diyerek sinemanın önemine değinmiş ve bu sanat ile insanlık ülküsü arasında çok güzel bir paralellik kurmuştur.

\footnotetext{
${ }^{75}$ Özgü, a.g.m, s.54.

${ }^{76}$ Tiyatronun halk eğitiminde oynadığı önemli ve çok yönlü rolü iyi bilen Atatürk, tiyatronun sanat olarak gelişmesini istediği kadar bu sanatı inkılâbı yaygınlaştırmak, Türk milletine temel olacak ilkeleri tanıtmak ve sağlamlaștırmak amacıyla da kullanmak istemiștir. "Akın", "Mete", "Özyurt", "Attila" gibi tarihî oyunlar ve "Cumhuriyet Çocukları", "İnkllâp", "On Yllın Destanı" gibi inkılâbı yaygınlaştırmaya yönelik oyunlar Atatürk'ün önerileri ile yazılmıştır Pınar Kolukısa, "Atatürk'ün Tiyatro Çalışmaları", Devlet Tiyatrosu, C.57, Ankara, 1973, s.6-7.

${ }^{77}$ Türklerin Orta Asya'dan Anadolu'ya ve Batı'ya doğru yayılıp genișlemelerini anlatan bu oyunu izlerken Atatürk'ün gözyaşlarını tutamadığı görülmüştür. Oyun bittikten sonra ilk alkışlar yine Atatürk'ün locasından yükselmiştir. Ardından Atatürk, başta Muhsin Ertuğrul olmak üzere oyunda rol alan bütün sanatçıları huzuruna davet ederek kutlamıştır Cemal Granda, Atatürrk’ün Ușağının Gizli Defteri, Anekdot yayınevi, Ankara, 2010, s.143-144. Lütfi Ay, “Atatürk ve Tiyatro”, Devlet Tiyatrosu, C.57, Ankara, 1973, s.5.

${ }^{78}$ Özgü, a.g.m., s.54-55.

${ }^{79}$ Yücel, a.g.m., s.56.
} 
İstiklâl Savaşı sırasında "Ordu Film Dairesi" tarafından belgesel film niteliğinde "Ístiklâl/İzmir Zaferi" adlı filmin hazırlanmas1, ${ }^{80}$ Anadolu'da verilen bağımsızlık mücadelesi hakkında halkın bilgilendirilmesi konusunda sinemanın da etkin bir iletișim aracı olarak kullanılmak istendiğini göstermektedir. 1923'te Halide Edip (Adıvar) Hanım'ın “Ateșten Gömlek”, bir y1l sonra da Reşat Nuri (Güntekin) Bey'in "Bir Gece Rüyası" adlı oyunundan uyarlanan "Ankara Postast" adlı eserleri sinema filmi olarak çekilmiştir. Bunu "Düşman Denize Dökülüyor" adlı belgeselin çekilmesi takip etmiştir. Türk milletinin bağımsızlık savaşını konu alan bu film ve belgeseller savaş yıllarının bozuk ekonomik yapısı içinde büyük maddi sıkıntılar neticesinde çekilebilmişlerdir. ${ }^{81}$

Atatürk'ün Muhsin Ertuğrul'un 1932'de çektiği "Bir Millet Uyanıyor" filminin senaryosunu bizzat incelemesi, dönemin genç sinemacisı Fuat Uzkınay'ın 1934'te hazırladığı İstiklâl Savaşı belgesellerini yetersiz bulup, bunların genişletilmesi için talimat vermesi, üç yıl sonra bu genişletilme işleminin olumlu bir sonuca ulaşamadığını anladığında: "Ben hayattayım. Millî Mücadele'ye ait bütün evrâkım, kilıcım, çizmem hâlihazırda mevcut olduğuna göre çă̆ırdiğınız anda bana düşen vazife ve görevi yapmadım mı? Böyle bir teklif karşısında kalsam memnuniyetle kabul eder, bir artist gibi filmde rol alır, hatıraları canlandırırdım. Bu millî bir vazifedir. ${ }^{, 82}$ demesi sinema ile ilgisinin en somut örneklerinden biridir.

Atatürk, Türk sinemasının henüz gelişmeye başladığı söz konusu dönemde çekilen yerli filmler ile yakından ilgilenmiş, bu filmleri izleyebilmek için adeta firsat kollamıştır. Mesela, 1931'de ilk sesli Türk filmi olarak çekilen ve büyük başarı kazanan "İstanbul Sokaklarında" adlı filmin övgüsünü işitir işitmez yakın arkadaşlarıyla birlikte bu filmi izlemiş, gece döndüğünde uşağı Cemal Granda'ya: "Çelebi Efendi, iyi vakit geçirdik. "83 diyerek memnuniyetini dile getirmiştir. ${ }^{84}$ Atatürk; senaristleri, yönetmenleri ve oyuncuları daima takdir etmiş ve onlarla gurur duyduğunu çeşitli vesilelerle vurgulamıştır.

80 Fethiye Erbay-Mutlu Erbay, Cumhuriyet Dönemi (1923-1938) Atatürk’ün Sanat Politikası, Boğaziçi Üniversitesi yayınları, İstanbul, 2006, s.176.

${ }^{81}$ Terane Memmedova, "Atatürk ve Sinema", Uluslar arası Atatürk ve Güzel Sanatlar Sempozyumu Bildirileri (26-27 Ekim 2001/Ankara), Yay.haz.: Nail Tan ve Hayrettin İvgin, Cumhuriyet, Kültür ve Tanıtma Vakfı yayınları, Ankara, 2005, s.94-95.

${ }^{82}$ Halit Refĭğ, "Türkiye'de Devletin Sinema Siyaseti", Atatürk ve Sanat Sempozyumu, (2628 Ekim 1981), İstanbul Güzel Sanatlar Akademisi yayın no:86, İstanbul, 1983, s.100.

${ }^{83}$ Atilla Dorsay, “Atatürk ve Sinema”, Atatürk ve Sanat Sempozyumu, (26-28 Ekim 1981), İstanbul Güzel Sanatlar Akademisi yayın no:86, İstanbul, 1983, s.92.

${ }^{84}$ Granda, a.g.e., s. 133 . 
Cumhuriyet'in 10. y11 dolayısıyla yapılacak gösterilerde sinemadan yararlanmak düşüncesi güç kazandığı için o yıllarda belgesel film çekiminde başarılarıyla tanınan ünlü Sovyet yönetmen Sergey Yutkeviç ve yardımcısı Lev Oskaroviç Türkiye'ye davet edilmiştir. Bu sinemacılar, Reşat Nuri Güntekin ve Fikret Adil gibi yazarların da yardımıyla Ankara'nın Türk İstiklâl Savaşı ve İnkılâbı'nda oynadığı rolden yola çıkarak savaşın ve inkılâpların genel seyrini tasvir eden bir film çekmişlerdir. Atatürk'ün izni ve onayıyla hazırlanan bu filmin çekimi 1934 'te tamamlanmıştır. Büyük ilgiye mazhar olan söz konusu film "Türkiye'nin Kalbi; Ankara" adı ile Cumhuriyet' in 10. yıl kutlama törenlerinde yer almıştır. ${ }^{85}$

Türk sinema tarihinin başlangıç aşamasını teşkil eden bu süreçte Atatürk'ün konuya yakın ilgisi, sinema sanatının Türkiye'de sağlam temeller üzerinde ve hızlı bir şekilde gelişmesini sağlamıştır. Söz konusu dönemde Ankara, Bursa, İzmir, Konya ve Eskişehir gibi önemli merkezlerde açılan sinema salonları bu sanata verilen önemi göstermektedir. Cumhuriyetin ilk yılları itibariyle ülkenin toplumsal yapısının aynası olarak çekilen belgeseller ve sinema filmleri, gerek tema gerekse teknik bilgi anlamında ileriki y1llarda yetişen Türk sinemacıları için önemli bir kaynak teşkil etmiştir.

\section{Atatürk ve Dans, Halk Oyunları}

Tarih, arkeoloji ve etnoloji dallarında yeni kurulan fakülteler, Türk Tarih Kurumu, ve Halkevlerinin programlarının Atatürk'ün görüş ve projelerinden esinlenerek hazırlanması, Türk Ocakları'nda ve Köy Enstitüleri'nde halkbilimi/folklor konularında çalışmalar yapılması, Türkiyat mecmuasının çıkarılması Atatürk'ün halk kültürünün bilimsel açıdan ele alınması konusundaki yaklaşımını yansıtmaktadır. ${ }^{86} \mathrm{Bu}$ anlayış çerçevesinde Atatürk, halk kültürünün ve güzel sanatların önemli bir dalını teşkil eden dans ve halk oyunları ile de yakından ilgilenmiştir.

Gençlik yıllarından itibaren Batı danslarına ilgisi bilinen Atatürk, ${ }^{87}$ bunları daha çok bir salon dansı olarak kabul etmiştir. Özellikle Cumhuriyet balolarında musiki topluluklarına tango ve vals çaldırdığı, kendisinin de piste çıkarak dans edenlere eşlik ettiği bilinmektedir. İzleyenleri hayran bırakan bu danslar aynı zamanda modern dans konusunda Türk gençliğine birer ders teşkil etmiştir. ${ }^{88}$

\footnotetext{
${ }^{85}$ Fethiye Erbay-Mutlu Erbay, a.g.e., s.177.

${ }^{86}$ Sabahattin Türkoğlu, "Atatürk ve Folklor", Sanat Dünyamız, Yı1:8, S.22 (Özel sayı), İstanbul, 1981, s.22.

${ }^{87}$ Ali Fuat Cebesoy, Sınıf Arkadaşım Atatürk, İnkılâp yayınevi, İstanbul, 1999, s.39.

${ }^{88}$ Fethiye Erbay-Mutlu Erbay, a.g.e., s. 163.
} 
Bunun yanı sıra Atatürk, yiğitlik, mertlik ve kahramanlık duygularına tercüman olan Türk halk oyunlarına daha özel bir değer vermiştir. $\mathrm{Bu}$ kategoride zeybekler, Çaydaçıra, Erzurum oyunları ve Kafkas Türklerine ait oyunlar vardır ki bunların içinde Atatürk'ün en çok sevdiği halk oyunu "Zeybek" idi. ${ }^{89}$ Cumhuriyet'in 10. Y1lı münasebetiyle Ankara Halkevi'nde düzenlenen baloya davet edilen Rus Heyeti'nin Başkanı Voroşilof, orkestranın "Kazaska"* çalması üzerine kalkıp oynayınca, Atatürk de orkestraya bir zeybek çalmasını söylemiş ve ortaya çıkarak mükemmel surette zeybek oynamıştır. Daha sonra alkışlar içinde yerine otururken: "İ̧̧̧e bizim de böyle erkekçe bir oyunumuz var. "demiştir. ${ }^{90}$

Atatürk, kahramanlıklar yaratan Türk milletinin mert, cesur ve yiğit bir karakteridir. Dolayısıyla zeybek oyunu da O'nun karakteri ile bir bütünlük arz etmiştir. Nitekim, "Bu oyun milletimizin erkek oyunu, kahraman oyunudur; bilmek lâzım!",' diyerek bu oyunun önemini çeşitli vesilelerle vurgulamıştır. Bu yüzden çeşitli etkinlik programlarında ve balolarda zeybek oynamak, yakın arkadaşlarına oynattırmak ve musikisini çaldırmak Atatürk için adeta bir tutku hâlini almıştır. ${ }^{92}$

Atatürk, halk oyunları alanında yapılan çalışmaları titizlikle desteklemiştir. Örneğin, zeybek derlemelerinde, öğretiminde ve zeybek ekipleri kurulmasında büyük hizmetleri olan Selim Sırrı Tarcan, Atatürk'ün takdirine mazhar olmuştur. Selim Sırrı Tarcan'1n, birçok zeybek figürünü bir araya getirerek oluşturduğu ve "Tarcan Zeybeği" olarak anılan oyununu Atatürk tekrar tekrar izlemiştir. Bunu Türk millî oyunlarının sahne düzenine kavuşması açısından değerlendirmiş: "Artık, Avrupalılara bizim de mükemmel bir raksımı var diyebiliriz ve bu oyunu salonlarımızda, müsamerelerimizde oynayabiliriz", ${ }^{, 3}$ diyerek bu konudaki memnuniyetini dile getirmiştir.

Atatürk; el ele, kol kola, omuz omuza oynanan dostluk ve birliktelik zevkini tattıran halk oyunlarına da ilgi duymuştur. Sevdiği bu tür oyunların

\footnotetext{
${ }^{89}$ Türkoğlu, a.g.m., s.23.

*Kazaska: Kafkas karakterinde, hareketli bir halk oyunudur.

90 Enver Behnan Şapolyo, Kemal Atatürk ve Millî Mücadele Tarihi, Ekicigil matbaası, 3.bask1, İstanbul, 1958, s.527-528.

${ }^{91}$ Fahrettin Altay, 10 Yıl Savaş ve Sonrası (1912-1922), Eylem yayınları, Ankara, 2008, s. 394.

92 Yakın arkadaşlarından olup iyi zeybek bilen Şükrü Saraçoğlu'nun bazı kereler Atatürk'ün isteğiyle zeybek oynadığı bilinmektedir. Katıldığı davetlerde çevresindekilerin oynadığ 1 zeybeği beğenmediği takdirde Atatürk'ün bunu bir firsat telakki ederek kalkıp zeybek oynadığı da yakınları tarafindan anlatılan hatıralar arasındadır (Türkoğlu, a.g.m., s.25).

${ }^{93}$ Atatürk'ün Söylev ve Demeçleri, C.II, s.240.
} 
başında Rumeli'nin karakteristik oyunlarından biri olan "Hora" gelmekteydi. Hora'nın yalnız Türkler tarafından değil, tüm Balkanlar'da ve daha çok Yunanistan'da oynandığını bilen Atatürk, halk oyunlarının siyasi sınır tanımayan, uluslar arasında dostluk ve barıș için yakınlaştırıcı bir unsur olduğunu çeşitli vesilelerle vurgulamıştır. Uluslararası bir etkinlik olan Balkan Festivali'nin 1936'da İstanbul'da düzenlenmesi bunun en bariz kanıtlarından birini teşkil etmiştir. Balkan Festivali'ne katılan Balkan ülkelerinin halk oyunları grupları için İstanbul'da Beylerbeyi Sarayı'nda bir balo düzenlenmiş ve davet edilen gruplara Atatürk tarafından ayrı ayrı iltifat edilmiştir. Yukarıda değindiğimiz üzere "Hora" gibi bazı Balkan halk oyunları ile Türk halk oyunları arasındaki benzerliğe istinaden, ekiplerin oyunları sırasında birbirlerine eşlik etmelerini istemiş ve hatta kendisi de bu ekiplerin arasına katılmıştır. Atatürk'ün komşu ülkelerin sanatçılarıyla el ele, kol kola oyun oynaması uluslar arası alanda dostluğu ve barışı simgelemiştir 94

Atatürk, söz konusu etkinlikler sırasında Türk ekiplerinin oyunlarını da büyük bir dikkat ve memnuniyetle izlemiş, hatta Artvinlilerin oyunlarına bizzat katılarak büyük bir coşkunluk yaratmıştır. Artvinliler, Atatürk'ün bu sıcak yakınlı̆̆ değiştirmişlerdir. ${ }^{95}$

Sonuç itibariyle, Türkiye'de halk kültürü çalışmalarının önemli bir boyutunu oluşturan halk oyunlarının derlenmesinde, benimsenmesinde ve sevilmesinde Atatürk döneminde yapılan çalışmaların etkin bir rol oynadığını açıkça söyleyebiliriz.

\section{Atatürk ve Edebiyat}

Atatürk'ün öğrencilik ve gençlik yıllarından itibaren edebiyata ilgi duyduğunu, Namık Kemal'in, Tevfik Fikret'in, Mehmet Emin Yurdakul'un,

\footnotetext{
94 Türkoğlu, a.g.m., s.24-25. Atatürk'ün 2 Eylül 1936 akşamında Beylerbeyi Sarayı’ndaki Balkan Festivali'nde Kâzım Dirik'e okuttuğu not, halk oyunlarının halkların birbirine yaklaşması, bütünleşmesi ve ortak insanlık ideallerine beraber yürümesi konusundaki rolüne işaret etmiştir. $\mathrm{Bu}$ not şu şekildedir: "Huzurunuzda konuştuğum Balkanlılar! Bulgarlar, Helenler, Romanyalılar, Türkler, Yugoslavyalılar, siz hepiniz ne kadar birbirinizden ayırt edilmez insanlar olduğunuzu, bu gece, birbirine girmiş, candan arkadaşlık ve samimiyet yaşayışınızla bir defa daha göstermiş, ispat etmiş bulunuyorsunuz. Biz Türklerin, bu temiz insanlık camiastyla beraber oluşu, beraber olduğunu göstermeye yarayan her vaziyetten ne kadar büyük saadet duyduğumuzu söylemeye hacet yoktur. Beșeriyette saadet, iște böyle insanoğullarının birbirine yaklaşmasl, insanların birbirini sevmesi, hepsinin temiz his ve düşüncelerini birleştirmesiyle olacaktır. Bu geceki birleşik vaziyetimiz, bu ümen idealin yüksek beşaretidir.” Cumhuriyet Gazetesi, “Atatürk'ün 2 Eylül 1936'da Balkan Festivali'nde Kâzım Dirik'e ve Bir Türk Çocuğuna Yazdırtıp Okuttuğu Notlar”, 05.09.1936.

${ }^{95}$ Tahir Kutsi Makal, “Atatürk ve Folklor”, Türk Edebiyatı, İstanbul, 1980, S.85, s.22-25.
} 
Ziya Gökalp'in vatan, hürriyet ve milliyetçilik ile ilgili eserlerini okuduğunu, ${ }^{96}$ bunlara konuşmaları sırasında atıflarda bulunduğunu biliyoruz. ${ }^{97}$ Atatürk'ün edebiyata olan ilgi ve sevgisi Manastır Askerî İdâdîsi'nde edebiyata meraklı ve şiirler yazan arkadaşı Ömer Naci'nin etkisiyle başlamış ${ }^{98}$ bu ilgi İdâdî'deki bir hocasının, şiirle ilgilenmesinin kendisini askerlikten uzaklaştıracağına dair uyarılarına rağmen ${ }^{99}$ gün geçtikçe artmıştır. Nitekim sonraki yıllarda Türk hitâbetinin timsâli hâline gelen nutukları ile Türk milletini aydınlığa taşıyan Atatürk, ${ }^{100}$ hitâbet sanatının sırlarını: "Güzel konuşmak için serbest olmak ve kelimelerin manâlarını, yerinde yapılan jestlerle takviye etmek lâzımdır." şeklinde açıklamıştır. ${ }^{101}$ Atatürk, büyük bir "hâtip" olduğu kadar Türkçe'yi çok iyi kullanan bir "nâsir" olarak da kabul edilmiştir. ${ }^{102}$

Atatürk, edebiyatı da güzel sanatlar içinde değerlendirmiş ve tanımını: "Söz ve manâyl, yâni insan dimağında yer eden her türlü bilgileri ve insan karakterinin en büyük duygularını, bunları dinleyenleri veya okuyanları çok alâkalı kılacak surette söylemek ve yazmak sanatı" şeklinde yapmıştır. ${ }^{103}$ Biçimsiz bir sözün etkili olamayacağının farkında olarak, gittikçe geniş

\footnotetext{
96 Atatürk, şiiri tıpkı çok sevdiği Namık Kemal gibi vatan ve millet yolunda heyecan uyandırıcı bir sanat, çok takdir ettiği Tevfik Fikret gibi ilim, fikir ve vicdan hürriyetinin kazanılmasında, korunup geliştirilmesinde başlıca faktörlerden biri, hitabet sanatını ise asker ve devlet adamı vasfinı tamamlayan vazgeçilmez bir unsur olarak görmüştür Önder Göçgün, Edebiyat Dünyası ve Atatürk, Atatürk Kültür Merkezi yayını, Ankara, 1995, s.1.

${ }^{97} \mathrm{Bu}$ konu ile ilgili iki örnek vermekle yetineceğiz: Batı Anadolu topraklarının hâlen Yunan işgali altında bulunduğu 13 Ocak 1921 tarihi itibariyle TBMM kürsüsünde Atatürk, sevdiği şair Namık Kemal'e atıfta bulunarak: "Namık Kemal demiştir ki, 'Vatanın bağrına düşman dayadı hançerini, yok mudur kurtaracak bahtı kara maderini?' işte bu kürsüden, bu Meclis-i Âli'nin reisi sıfatıyla hey'et-i âlinizi teşkil eden bütün a'zânın her biri nâmına ve bütün millet nâmına diyorum ki; Vatanın bağrına düşman dayasın hançerini, bulunur kurtaracak bahtı kara maderini.." şeklinde bir konuşma yapmıştır. Tevfik Fikret'in "Elbet sefil olursa kadın, alçalır beşer" mısrası da Atatürk'ün türlü vesilelerle zikrettiği veciz söylemler arasındadır (Peker Y1lmaz, “Atatürk ve Edebiyat”, Kemalizm, S.225, İstanbul, 1981, s.18).

98 Atatürk, güzel söylemek ve yazmak hevesinin kendinde hep bulunduğunu belirterek, Manastır Askerî İdadisi'nde teneffüs zamanlarında bile arkadaşlarıyla hitâbet talimleri yaptıklarını belirtmiştir Atatürk'ün Söylev ve Demeçleri, C.III, s.41.

${ }_{99}$ Afet İnan, "Atatürk ve Edebiyat", Millî Yol Atatürkçülük, S.1, 31 Ocak 1971, s.17. Olay1 benzer şekilde aktaran şu esere bkz.; Cebesoy, a.g.e., s.17.

${ }^{100}$ Taha Toros, Türk Hâtipleri, İstanbul, 1950, s.83. Atatürk'ün Büyük Nutku, bunların en önemlisini teşkil eder. Nutuk, Türkiye'nin siyasi tarihi için önemli bir belge olmakla birlikte, siyasi hitâbet türünün de bir şaheseri olarak kabul edilmektedir Göçü̈n, a.g.e., s.27.

${ }^{101}$ Kocatürk, a.g.e., s.157.

${ }^{102}$ Müjgân Cumbur, "Atatürk ve Edebiyat”, Türk Edebiyatı, C.2, S.22, İstanbul, 1973, s.1518.

${ }^{103}$ İnan, a.g.e., s.393-394.
} 
kitlelere ulaşan hayat görüşü ile halkın psikolojisine inmiş, düşünce ve hislerini milletine edebî bir biçimde aktarmayı tercih etmiştir. ${ }^{104}$

Edebiyatın toplum hayatını şekillendiren ve nesiller arasında kültür köprüsü kuran en önemli eğitim vasıtalarından biri olduğuna inanan Atatürk, edebiyat öğretimi konusunda Maarif Vekâleti'nden: "Türk çocuklarının yeteneklerini, karakterlerindeki sağlamlıklarını, duygularındaki coşkunluğu zorlamadan, olduğu gibi ifadeye alıştırmak ${ }^{, 105}$ hususlarına önem verilmesini istemiştir. Çünkü, Türk çocuğunun kendisini dinleyenleri millî hedefler doğrultusunda peşine takabilmesinin ilk koşulu, özgün bir edebî üslûba sahip olmasidir.

Atatürk, edebiyatı ve şiiri sevdiğini her firsatta dile getirmiştir. ${ }^{106}$ Sanat ve edebiyat meclisi hâlini alan davetlerinde devrin edipleri ve sanatçıları sıklıkla yer almıştır. Bu sohbetler sırasında fikir alışverişinde bulunduğu ediplerle şiirler okumak, bazı eserlerin, edebî tarif ve tasvirlerine girmek Atatürk'ün sıkça şahit olunan özellikleri arasında yer almıştır. ${ }^{107}$

Devrindeki şairleri yakın bir ilgiyle takip eden Atatürk: "İnsanlarda birtakım ince, yüksek ve temiz duygular vardır ki insan onlarla yaşar. İşte o ince, yüksek, derin ve temiz duyguları en ziyade duyabilen ve diğer insanlara duyurabilen, şairdir. "108 diyerek şairlerin ulvî özelliklerine temas etmiştir. Türk şairlerinin geniş bir kültür birikimine sahip olmaları ve tarihi iyi bilmeleri gerektiğini düşünmüştür. Bu anlamda Doğu ve Batı kültürlerinin temellerini kavramış ve geniş bir tarih bilgisine sahip bir şair olan Yahya Kemal Beyatlı, Atatürk'ün takdir ettiği şairler arasında yer almıştır. ${ }^{109}$

29 Ağustos 1928 günü Dolmabahçe Sarayı'nda Halit Fahri Ozansoy'a

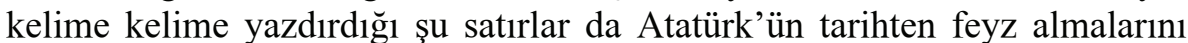
istediği Türk şairlerine "millî şiiir" yolunda önemli bir tavsiyesi niteliğindedir:

"Kesinlikle, dâhil olduğun parlak Türk devrinde şâir olduğunu ispat edeceksin. Şiirlerin; şen, neşeli, faal Türk milletinin sevinç, neşe, faaliyet, his ve hareketlerini şaklyacaktır. Buna mevcudiyetini hasredeceksin! Kökü

\footnotetext{
104 Özgü, a.g.m., s.33.

105 İnan, a.g.e., s.394.

106 Atatürk, edebiyata ve şiire dair bu görüşünü 18 Ağustos 1917'de Tevfik Fikret'in ölümünün 2. yılı münasebetiyle, şairin Rumelihisarı'ndaki evinde düzenlenen anma töreninde Çanakkale şiirleri ile tanınan şair İbrahim Alâettin Gövsa'ya söylemiştir İbrahim Alâettin Gövsa, Acılar, Türkiye İș Bankası Kültür yayınları, ilavelerle 2. baskı, Ankara, 1966, s.14-15.

107 Ökçün, a.g.e., s.11-12.

${ }^{108}$ Kocatürk, a.g.e., s.157.

109 İnan, a.g.e., s.399.
} 
çok büyük olan, dalları ondan daha büyük olacak olan bir ırkın çocuğu olarak, mensup bulunduğun millete lâyık şiirler yazacaksın. Bunu yaparsan kimse itiraz edemez ve kabul ediyorum $k i$, o zaman muvaffak oldum diyeceksin.",110

$\mathrm{Bu}$ ifadelerden de anlaşılacağı üzere Atatürk, şiir ile millî kültür arasında yakın bir ilişki kurmuş ve milletin duygularını ifade etmek konusunda şairlere önemli sorumluluklar yüklemiştir.

Bütün bunları destekler mahiyette Atatürk'ün "Dil ve Harf İnklâbı" konusundaki fikir ve görüşlerine değinmekte fayda vardır. Osmanlı Devleti'nin son döneminde Türk dili üzerinde artan ilmî çalışmalar Selanik'te 1911'den itibaren Ömer Seyfettin, Ali Canip Yöntem ve Ziya Gökalp'in Genç Kalemler Dergisi aracılığıyla ortaya koydukları "Yeni Lisân" akımı ile yeni bir mecraya girmiş ve bu akım Arapça ve Farsça'nın Türk dili üzerindeki tahakkümünü kırmaya çalışarak dilde birlik fikrini işlemeye başlamıştır. ${ }^{111}$ Bununla birlikte Türk dilinin özgün bir kimliğe kavuşması konusunda bu çalışmaların yeterli olduğunu söylemek mümkün görünmemektedir. Atatürk, dil sorununu bir bütün olarak ele almış, sorunun köklerine inmiş ve bunun için ilk olarak bir alfabe değişikliği yoluna gitmiştir. Kabul edilen Latin kökenli yeni Türk alfabesiyle Türk milleti hem okuma yazma kolaylığına kavuşmuş ${ }^{112}$ hem de dilini yabancı dillerin boyunduruğundan kurtarma ${ }^{113}$ yolunda önemli bir adım atmıştır. Nitekim söz konusu değişimlerden sonra Türk dili ve edebiyatı özgün bir mecrada seyrini sürdürmüş ve kısa sürede meyvelerini vermeye başlamıştır.

Bu konuyla ilgili son olarak, Atatürk'ün edebiyat alanında da halka doğru giderek ve halk arasındaki konuları işleyerek millî ve özgün bir edebî tarz yaratmak çabası içinde olduğunu açık bir şekilde söyleyebiliriz. ${ }^{114}$

\section{Atatürk ve Resim, Heykel, Mimari}

Türkler, tarihlerinin ilk dönemlerinden itibaren resim sanatıyla ilgilenmişlerdir. İslâmiyet'in kabulü ile birlikte, Müslümanlar arasında İslâm büyüklerinin tasvirlerinin yapılması hoş karşılanmamış, bu makul anlayış

110 Halit Fahri Ozansoy, Edebiyatçılar Çevremde, Sümerbank Kültür yayınları 5/109, Ankara, 1970, s.262-263.

${ }^{111}$ Genç Kalemler dergisi Türkçeleşmenin başlıca iki esasını ortaya atmıştır. Bunlar: "Bir dil, yabancı bir dilden kelime alabilir, fakat kaide alamaz ve konuşma dilinde Türkçesi olan kelimenin, Arapça ve Farsçasını kullanmamalıyız." esaslarıdır Atay, a.g.e., s.471.

${ }^{112}$ Atatürk'ün Söylev ve Demeçleri, C.II, s.272.

${ }^{113}$ Kocatürk, a.g.e., s.149.

${ }^{114}$ Enver Behnan Şapolyo, Kemal Atatürk ve Millî Mücadele Tarihi, Berkalp Kitabevi, Ankara, 1944, s.372-373. 
zamanla her tür tasvir ve heykelin cahiliye dönemine geri dönüşe neden olabileceği doğrultusundaki zorlama yorumlarla yerini lüzumsuz bir endişeye bırakmıştır. Böylelikle Türk resim sanatında biçim değişikliği olmuş ve bu sanat daha çok süsleme sanatı olarak varllğını sürdürmüştür. Söz konusu dönem itibariyle başta mimarlık olmak üzere hat, minyatür, tezhip gibi kitap sanatlarında ve diğer el sanatlarında eşsiz örnekler verilmesine rağmen resim ve heykel sanatları ihmal edilmiştir. Fatih Sultan Mehmet (1432-1481) gibi resim, Sultan Abdüzaziz (1830-1876) gibi heykel sanatına ilgi duyan padişahlara rağmen bu anlayış halk kitleleri arasında pek de yer edinememiştir. Netice itibariyle Türkler yüzyıllarca söz konusu sanatlarla esaslı bir şekilde meşgul olmamışlar ve bu anlayış Cumhuriyet'in ilk yıllarına kadar Türklerde resim ve heykel sanatının gelişmesine sekte vurmuştur. ${ }^{115}$

$\mathrm{Bu}$ anlamda şunu vurgulamakta fayda vardır ki, Atatürk'ün güzel sanatlar alanında yaptı̆̆ en büyük hizmet, söz konusu sanat dallarının gelişmesini imkânsızlaştıran bu gibi anlayış ve engelleri ortadan kaldırması olmuştur. ${ }^{116}$ Batı'da Rönesans ile başlayan güzel sanatlardaki değişim ve gelişim sürecine benzer bir süreç Atatürk'ün kurduğu çağdaş Cumhuriyet'in ilkeleri ve 1şı̆̆ 1 ile Anadolu topraklarında da yaşanmıştır. Böylece Türkiye'de sanatsal faaliyetler yeni bir ivme kazanmış, resim ve heykelcilik sanatları da kısa zamanda hızlı bir gelişim göstermiştir. ${ }^{117}$

Atatürk'ün çağdaş düşüncesi her alanda olduğu gibi resim ve heykel alanında da uygulamaya geçmiştir. 1924'te açılan 6. Galatasaray Sergisi'nde Atatürk'ün sanatçıları kutlaması ve bazı resimlerini satın alması sanatçılar arasında büyük bir memnuniyet yaratmıştır. Devlet adamları için de iyi bir örnek teşkil eden bu tutum gittikçe yaygınlaşarak bakanlıklar ile belediyelerce de benimsenmiştir. ${ }^{118}$ Takip eden süreç içinde Galatasaray Sergisi'nin her yıl düzenli olarak Ankara'da açılmasına karar verilmiş ve bu Bakanlar Kurulu kararı ile yasalaşmıştır. Yayımlanan "Resmî Sergiler Yönetmeliği" ne göre, sergiyi düzenleyecek bir kadro oluşturulmuş ve sergi sorumluluğuna Sami (Yetik) Bey getirilmiştir. Söz konusu yönetmelikle sanatçılara ödül olarak altın, gümüş, bronz madalyalar verileceği ve müze oluşturmak amacıyla Türk sanatçılarından her yıl belli sayıda eser alınacağı

\footnotetext{
${ }^{115}$ Esin Dal, “Atatürk Döneminde Resim ve Resim Tartışmaları”, Sanat Tarihi Yıllığı, C.XII, İstanbul Üniversitesi Edebiyat Fakültesi Sanat Tarihi Araştırma Merkezi yayınları, (Ayrı basım), İstanbul, 1983, s.6.

${ }^{116}$ Giritli, a.g.m., s.22.

${ }^{117}$ Dal, a.g.m., s. 9-10.

${ }^{118}$ Gültekin Elibal, Atatürk ve Resim-Heykel, Birinci basım, İstanbul, 1973, s.61.
} 
belirtilerek sanatçılar taltif edilmiş; böylece devlet, sanatçıları destekleyici bir role bürünmüştür. ${ }^{119}$

Söz konusu süreçte, sergilenen eserlerde denenen yeni anlayışların ve resimlerin basin ve yayın organları vasitasıyla akademik anlamda tartışılmaya başlanması Türk resim sanatı için bir olgunlaşma safhasını teşkil etmiştir. ${ }^{120}$

1924'te yürürlüğe girmiş olan "Tevhîd-i Tedrîsât Kanunu” ile resim, heykel, sanat tarihi eğitimleri ve bu eğitimleri yürüten kuruluşlar da yeniden gözden geçirilmiştir. ${ }^{121}$ Böylelikle 1883'te açılmış olan "Mekteb-i Sanâyi'-i Nefíse-i Şâhâne","122 İstanbul-Fındıklı'daki sarayın tahsisi ile "Devlet Güzel Sanatlar Akademisi" ${ }^{123}$ ne dönüştürülmüş, aynı yıl bilim, teknik ve sanat alanlarında bilgi birikimi sağlamak amacıyla yurt dışına 22 kişilik bir öğrenci grubu gönderilmiştir. Bu öğrencilerden Hayrullah Örs, Mâlik Aksel, Şinasi Barutçu, İsmail Hakkı Uludağ ve Mehmet Ali Atademir ${ }^{124}$ 1928-29 yıllarında Türkiye'ye dönerek Gazi Eğitim Enstitüsü 'nde "Resim IŞS Bölümü̈"nü kurmuşlar ve burada öğretmenlik yapmışlardır. ${ }^{125}$ Refik Fazıl (Epikman), Cevat Hâmit (Dereli), Mahmut Fehmi (Cûda), Muhittin Sebati ve Ratip Aşir (Acudoğu) gibi ressam ve heykeltıraşlar ise Türkiye döndüklerinde "Müstakil Ressamlar ve Heykeltıraşlar Birliği" ${ }^{126}$ nin

\footnotetext{
${ }^{119}$ Mete Tunçay ve diğerleri, Türkiye Tarihi 4, Çağdaş Türkiye (1908-1980), (Kolektif eser), İstanbul, 1995, s.539.

${ }^{120}$ Dal, a.g.m. s.13.

${ }^{121}$ Elibal, a.g.e., s.53.

${ }^{122}$ Osmanlı Devleti'nde 1883 'te açılan güzel sanatlarla ilgili bu ilk yüksek seviyeli okula, açıldığ zaman hoca olacak nitelikte ressam bulunamamıştı. Bu yüzden resim bölümünde "Valeri" ve "Varniye" adlarında iki İtalyan ressam, heykel bölümünde ise Yervant Oskan Efendi adında bir Ermeni heykeltıraş görev yapmıştır. Söz konusu okulda resim alanında bazı ilerlemeler görülmesine rağmen heykel alanında kayda değer bir ilerleme sağlanamamıștır Mahmut Cûda, "Cumhuriyet Dönemi Türk Resmi”, Atatürk ve Sanat Sempozyumu, (26-28 Ekim 1981), İstanbul Güzel Sanatlar Akademisi yayın no:86, İstanbul, 1983, s.74.

${ }^{123}$ Devlet Güzel Sanatlar Akademisi, 1983 tarihli Yüksek Öğretim Kurumu yasasıyla kurulan Mimar Sinan Üniversitesi'nin temelini oluşturmuş ve bu üniversitenin içinde Güzel Sanatlar Fakültesi olarak eğitimine devam etmiștir. Yine, Atatürk'ün altyapısını hazırladığı yol üzerinde 1957'de kurulan "Devlet Tatbiki Güzel Sanatlar Okulu” da günümüz itibariyle Marmara Üniversitesi Güzel Sanatlar Fakültesi adıyla resim ve heykel başta olmak üzere birçok sanat dalında çalışmalarını sürdürmektedir Yalçın ve diğerleri, a.g.e., s.208.

${ }^{124}$ Elibal, a.g.e., s.59.

${ }^{125}$ Serap Etike, "Atatürk ve Resim Eğitimi”, Uluslar arası Atatürk ve Güzel Sanatlar Sempozyumu Bildirileri (26-27 Ekim 2001/Ankara), Yay.haz.: Nail Tan ve Hayrettin İvgin, Cumhuriyet, Kültür ve Tanıtma Vakfı yayınları, Ankara, 2005, s.47-48.

126 Birliğin 1929 tarihli nizamnamesinde: "MRHB, resim ve heykel sanatlarının memleketimizde henüz inkişâf etmekte olduğunu nazart itibara alarak, bu sanatların terakkisi için sağlam eserlerin ve en emin temelin mevcudiyetini elzem addeder ve sanatın kendine has
} 
kurucuları arasında yer almışlardır. Bu birliğin 1929'da açılan ilk sergisini, başta Ankara ve İstanbul olmak üzere çeşitli illerde düzenlenen diğer sergiler takip etmiştir. ${ }^{127}$ Bütün bu gelişmeler neticesinde Türkiye'de resim sanatının temelleri atılmıştır.

Söz konusu dönemde resim sanatında "Atatürk" ve "Kurtuluş Savaşı" hâkim temayı teşkil etmiş ve kompozisyonlarda daha çok millî birlik, beraberlik ve bağımsızlık anlayışı vurgulanmıştır. ${ }^{128}$ Ressam Halil Dikmen'in "Istiklâl Harbi’nde Cephane Taşlyan Köylü Kadınlar" (1933) adlı yağlıboya resminde olduğu gibi Türk milletini bağımsızlığa taşıyan kadınları konu alan resimlerin yanı sıra, Cemâl Tollu'nun "Alfabe Okuyan Köylüler" (1933) ve Melek Celâl Sofu'nun "Türkiye Büyük Millet Meclisi'nde Kadın" (1936) adlı resimleri gibi kadınların eğitimine ve toplum hayatına katılımına yönelik konuların da bu dönemde yoğun olarak işlendiği görülmektedir. ${ }^{129}$

Cumhuriyet'in 10. y1l dönümünde, ressamların Anadolu'yu daha yakından tanımaları amacıyla yurt gezileri düzenlenmiş ve bu tecrübeler sonrasında ortaya çıkan Millî Mücadele temalı resimler "Türk Inkılâp Sergisi" adıyla sergilenmiş̧ir. Atatürk, söz konusu sergide heyecanını ve memnuniyetini gizlememiş, saatlerce sergide kalarak eserleri birer birer incelemiştir. ${ }^{130}$ Örneğin Ressam Sami (Yetik) Bey'in "Sarıkamış" adlı tablosu Atatürk'ün çok beğendiği ve: "Sarıkamış ve Kafkas cephesi facialarının canlı bir şahididir" demek suretiyle takdirlerini bildirdiği eserler arasında yer almıştır. ${ }^{131}$

1934’te Başbakan İsmet İnönü tarafindan bir "Sergievi Binası" açılmış, bunu sanatı korumak ve kollamak amaciyla "Ar Genel Direktörlüğü”nün kuruluşu takip etmiştir. Ar Genel Direktörlüğ̈̈’nün yapacağı işler TBMM'de görüşülmüş ve amacı: "Okullarda ve okullar dışında dramatik sanatlarla,

temiz ve yüksek serbestisi ile çallşarak hizmeti de gaye bilir.” denilmektedir. MRHB üyelerinin bir kısmı 1933 yılında "D Grubu" adında yeni bir resim birliği kurmuştur Dal, a.g.m., s.12.

${ }^{127}$ Dal, a.g.m., s. 12 .

${ }^{128}$ Latife Öztoprak, a.g.m., s.735.

129 Yıldız Kurtuluş, "Cumhuriyet'in Kuruluş Yıllarında Türk Resminde Yurttaş Kadın İmgesi”, Uluslar arası Atatürk ve Güzel Sanatlar Sempozyumu Bildirileri (26-27 Ekim 2001/Ankara), Yay.haz.: Nail Tan ve Hayrettin İvgin, Cumhuriyet, Kültür ve Tanıtma Vakfı yayınları, Ankara, 2005, s.82-84.

${ }_{130}$ Özgü, a.g.e., s.42.

131 Taciser Konuk, "Atatürk'ün Resim Sanatına Verdiği Önem ve Atatürk Portreleri”, Uluslar arası Atatürk ve Güzel Sanatlar Sempozyumu Bildirileri (26-27 Ekim 2001/Ankara), Yay.haz.: Nail Tan ve Hayrettin İvgin, Cumhuriyet, Kültür ve Tanıtma Vakfı yayınları, Ankara, 2005, s.157. 
musiki ve plastik sanat işlerinin ulusal ülküye uygun olarak yürümesine ve yücelmesine çalışmak ve bu çalışmanın sosyal ĕ̆itim bakımından gereği gibi verimli olması yollarını aramak ve göstermek. "132 şeklinde tespit edilmiştir.

Güzel sanatları çağdaş yaşamın kaçınılmaz bir zorunluluğu sayan Atatürk'ün direktifleri doğrultusunda Dolmabahçe Sarayı Veliaht Dairesi, Türkiye'nin ilk "Resim Galerisi" olarak 20 Eylül 1937'de halka açılmıştır. ${ }^{133}$ Böylece saraylarda, konaklarda, depolarda çürümeye terk edilmiş birçok eser toplanarak bu müzeye getirilmiştir. Ayrıca, eski ve yeni kuşaktan birçok sanatçının eserleri, tabloları ve heykelleri için ayrı ayrı salonlar tahsis edilerek söz konusu eserler koruma altına alınmıştır. Müzenin açı1ışında bulunan Atatürk, salonları tek tek gezmiş, her tablonun ve heykelin önünde uzun uzun durmuş ve Müze Müdürü Halil Dikmen'den Türk resminin değişim ve gelişim tarihi hakkında bilgi almıştır. ${ }^{134}$ Müzenin açı1ışı münasebetiyle Atatürk, Türk sanatçılarının kısa zamanda Türk kültürüne ve dünya medeniyetine yeni ve özgün sanat eserleri kazandıracaklarına dair inancını dile getirmiştir. ${ }^{135}$

Atatürk'ün resim sanatına bakışında da insanlık ülküsü ve hümanist anlayış hep ön plandadır. Başkumandanlık Meydan Muharebesi'nde elde edilen zaferin ardından İstanbul'dan Çankaya Köşkü'ne asılmak üzere gönderilen, yerde yatan Yunanlı askere bir Osmanlı askerinin süngüsünü saplamasını tasvir eden tablo Atatürk'ün talimatıyla derhâl içinde getirildiği sandığa tekrar kapattırılmış ve çatı arasına taşıttırılmıştır. ${ }^{136}$

Türkiye'de heykel sanatının doğuşu da Atatürk'ün öncülüğünde olmuştur. Atatürk, bu konudaki hassasiyetini henüz Cumhuriyeti ilân etmeden dile getirmeye başlamıştır. 1923 yılı başlarındaki Batı Anadolu gezisi sırasında Bursa Şark Sineması'nda yaptığı bir konuşmada: "Dünyada medenî, ileri ve olgun olmak isteyen herhangi bir millet, mutlaka heykel yapacak ve heykeltıraş yetiştirecektir." demiş ve o zamana kadar gelişim gösteremeyen bu sanat dalının medeniyet yolundaki önemine ve gerekliliğine işaret ederek uzun bir açıklamada bulunmuştur. Atatürk, konu

\footnotetext{
${ }^{132}$ TBMM Zabit Ceridesi, C.4, 1935, s.10.

${ }^{133}$ Resim Galerisi'nin kapısının üstünde: “Atatürk'ün emriyle 1937'de tesis edilmiştir.” sözü bulunmaktadır Özgü, a.g.m., s.42-43. Atatürk, 1937 Kasımı'nda TBMM'nin 5. döneminin 3. toplanma yılını açarken "Illk resim galerimizi de bu yıl açmış bulunuyoruz." diyerek Meclis'i bu konu hakkında bilgilendirmiştir Atatürk'ün Söylev ve Demeçleri, C. I, s.420.

${ }^{134}$ Nurullah Berk, "Atatürk ve Sanat", Varlık Dergisi, 1 Kasım 1962, S.585, s.12. Melahat Özgü, “Atatürk Sergi ve Müzede”, Türk Dili, C.12, S.46, 1 Kasım 1963, s.100. 
hakkındaki sözlerine: "Bir millet ki resim yapmaz, bir millet ki heykel yapmaz, bir millet ki bilimin gerektirdiği şeyleri yapmaz; itiraf etmeli ki o milletin ilerleme yolunda yeri yoktur. Oysaki bizim ulusumuz, gerçek nitelikleriyle uygarlı̆̆a erişmeye lâyıktır, uygarliğa erişecektir ve ilerleyecektir. "137 diyerek son vermiştir. İşte bu anlayış ve sezgi neticesinde resim ve heykel sanatları Cumhuriyet ikliminde ve topraklarında kök salmaya başlamıştır.

İstanbul Devlet Güzel Sanatlar Akademisi'nin açılışıyla birlikte “Heykel Bölümü"nde Mahir Tomruk, İhsan Özsoy ve Nijat Sirel gibi Avrupa'da heykel sanatına ilişkin eğitim almış heykeltıraşlar görev yapmışlardır. ${ }^{138}$ Almanya'dan davet edilen, 1937'den itibaren akademide "Bölüm Şefi" olarak görev yapan ünlü heykeltıraş Rudolf Belling Türkiye'de heykel sanatının öncülügünü yapmış ve Türk sanat tarihinde iz bırakan ünlü heykeltıraşları yetiştiren hoca olmuştur. ${ }^{139}$

Cumhuriyet döneminin başlangıcını teşkil eden bu süreçte yapılan heykellerin konusu daha çok, Atatürk veya Kurtuluş Savaşı'nda Türk milletinin çektiği cefaları ve yaptığı fedakârlıkları işleyen sahnelerdir. ${ }^{140}$

Atatürk, Türk tarih ve kültürüne hizmet etmiş büyük şahsiyetlerin heykel ve anıtlarının yapılması konusunda da hassasiyetle durmuş, millî kimliğin inşası yolunda büyük önem arz eden bu düşünce çerçevesinde Fatih Sultan Mehmet, Kanuni Sultan Süleyman ve İbni Sina gibi Türk büyüklerinin heykellerinin yapılmasını istemiştir. ${ }^{141}$ Büyük Türk Denizcisi Barbaros Hayrettin Paşa'nın İstanbul'da dikilen heykeliyle ilgili çalışmalara özel ilgi göstermesi, sanatını takdir ettiği Mimar Sinan için eserlerinin yoğun olarak bulunduğu İstanbul ve Edirne şehirlerinde, diğer Türk büyükleri için de Cumhuriyet'in başkenti Ankara'da birer anıt ve heykel dikilmesi yolunda talimatta bulunması Atatürk’ün bu konudaki düşüncelerini açik bir şekilde

\footnotetext{
${ }^{137}$ Atatürk'ün Söylev ve Demeçleri, C.II, s.70-71.

${ }^{138}$ Vildan Çetintaş, “Atatürk'ün Üniversite Reformu Çerçevesinde Türk Heykel Sanatındaki Gelişmeler”, Uluslar arası Atatürk ve Güzel Sanatlar Sempozyumu Bildirileri (26-27 Ekim 2001/Ankara), Yay.haz.: Nail Tan ve Hayrettin İvgin, Cumhuriyet, Kültür ve Tanıtma Vakfi yayınları, Ankara, 2005, s.22.

139 Soyut heykel çalışmalarıyla tanınan Alman sanatçı Rodolf Belling, 1937'de Türk Hükûmeti'nin davetiyle İstanbul'a gelmiş ve Güzel Sanatlar Akademisi Heykel Bölümü Başkanlığı'na getirilmiştir. Gelenekselliğe dayandırdığı modern heykelcilik anlayışıyla bölümü yeniden düzenlemiştir. 1952-1965 yılları arasında İstanbul Teknik Üniversitesi Mimarlık Fakültesi'nde ders vermiştir. Rudolf Belling'in hocalığını yaptığı Türk heykeltırașlar arasında Hüseyin Anka, Yavuz Görey, İlhan Koman, Hüseyin Gezer ve Şadi Çalık gibi ünlü isimler vardır Mete Tunçay ve diğerleri, a.g.e. s.454.

140 Mete Tunçay ve diğerleri, a.g.e., s. 545.

${ }^{141}$ İnan, a.g.e., s.243. Celâl Bayar, Atatürk'ten Hatıralar, İstanbul, 1955, s.117-118.
} 
ortaya koymaktadır. ${ }^{142}$ Böylelikle hem Türk tarihinde iz bırakmıs simaların anıların tazelemeyi, onları yeni nesle tanıtmayı, hem de bu sanat eserlerinin gelecek nesillere örnek teşkil etmesini arzu etmiştir.

Çalışmamızı Atatürk dönemindeki mimari anlayışa değinerek sonlandıralım. Mekteb-i Sanâyi'-i Nefîse-i Şâhâne'nin 1926'da Güzel Sanatlar Akademisi'ne dönüştürülmesiyle “Mimarlık Bölümü”nün başına Profesör Ernst Egli $^{143}$ getirilmiş ve bu tayin Türkiye'de çağdaş anlamda mimarlık eğitiminin başlangıç noktasını teşkil etmiştir. ${ }^{144}$

Atatürk, yetişecek genç Türk mimarlarından asrın bütün düşünce ve ihtiyaçlarına cevap verecek, ruhlarda hoş bir izlenim bırakacak, modern ve tamamıyla Türklüğe özgü bir mimari anlayış beklemiştir. Bu düşünceler doğrultusunda, millî mimariden örnekler veren Mimar Kemalettin ve Mimar Vedat gibi üstatları desteklemiştir. Bu mimarlar, yeniden imarına başlanan Ankara'da, eski Türk mimarlığından esinlenen üsluplar ile TBMM Binası, Ankara Palas, Vakıf Apartmanları, Gazi Eğitim Enstitüsü gibi önemli eserler meydana getirmişlerdir. ${ }^{145}$

\section{SONUÇ}

Ünlü İngiliz Edibi Friedrich Schiller, "Sanatlar, hürriyet tarafindan emzirilince büyürler." demiştir. Nitekim hürriyeti ve bağımsızlığı karakteri

142 Atatürk, 02.08.1935 tarihinde Türk Tarih Kurumu'na "Sinan'ın heykelini yapınız." talimatını vermiş ve nihayetinde heykeltıraş Hüseyin Anka tarafından yapılan anıt-heykel 1956'da Dil ve Tarih Coğrafya Fakültesi'nin bahçesine dikilmiştir Afet İnan, Mimar Koca Sinan, Türkiye Emlâk Kredi Bankası Neşriyatı no.3, Ayyıldız matbaası a.ş, Ankara, 1968. s.67.

${ }^{143}$ Avusturya kökenli İsviçreli mimar, 1927'de Maarif Vekâleti tarafından modern eğitim kurumlarının inşası için danı̧̧man mimar olarak Türkiye'ye çağrılmış ve 1936'ya kadar süren danışmanlığı sırasında Musiki Muallim Mektebi (Devlet Konservatuvarı), Ankara Üniversitesi Rektörlük Binası (1933), Mülkiye Mektebi (1935), Gazi Lisesi (1936) gibi birçok eğitim yapısını projelendirip inşa etmiştir. 1930'da İstanbul Güzel Sanatlar Akademisi Mimarlık Bölümü’nün eğitim programını yeniden düzenlemekle görevlendirilmiş ve akademinin öğretim kadrosunda görev almıştır. Burada “Şehircilik Enstitüsü̈”nü kurmuştur. Yüzeysel bir aktarmacılık yerine Türkiye'nin koşullarını ve birikimlerini gözeten, çevre kaygısı taşıyan bir mimarlık önermiş, Anadolu mimarlığının bilimsel olarak araştırılmasına ve "Millî Mimari Semineri”"ne önayak olmuştur A. Batu, "Egli, Ernst Arnold", Eczacıbaşı Sanat Ansiklopedisi, C.1, Yap1-Endüstri Merkezi Yayınları, İstanbul, 1997, s.503.

${ }^{144}$ Atatürk Türkiyesi'nin bu başarılı atılımlarını 1944'te kurulan İstanbul Teknik Üniversitesi'nin bünyesinde yer alan Mimarlık Fakültesi, 1956'da kurulan Ortadoğu Teknik Üniversitesi Mimarlık Fakültesi ve Türkiye'nin birçok şehrinde açılan benzer nitelikteki eğitim kurumları takip etmiştir Yalçın ve diğerleri, a.g.e., s.210.

${ }^{145}$ Yalçın ve diğerleri, a.g.e. s.209. 
olarak gören Atatürk'ün güzel sanatlar alanında yaptı̆ğ en önemli hizmet, güzel sanatların gelişmesini imkânsızlaştıran engelleri ortadan kaldırması olmuştur. Atatürk, güzel sanatlardaki gelişmeyi Türk İnkılâbı'nın en önemli unsurlarından biri saymıș ve Türk milletine çağdaşlaşmanın yolunu ancak bu alandaki başarıların açacağına inanmıştır. O'na göre güzel sanatlar, bir milletin hayat kaynaklarından birini teşkil eder. Sanattan ve sanatçıdan mahrum olan bir milletin bütünüyle bağımsız bir yaşam sürmesine imkân yoktur.

$\mathrm{Bu}$ yaklaşım doğrultusunda, yüzyıllarca ihmal edilen sanat dallarına eğilen Atatürk, Cumhuriyet'in ilk yıllarından itibaren konuyla ilgili gerekli yasal düzenlemelerin yapılmasına ve modern eğitim kurumlarının açılmasına önayak olmuştur. Bu eğitim kurumlarından kısa bir süre içinde birçok değerli sanatçı yetişmiştir. Güzel sanatlara bakışın yeniden şekillenmesiyle birlikte sanatç1lar türlü vesilelerle teşvik edilmiş ve onlara uygun çalışma imkânlarının yaratılması konusunda devlet erki görevli kılınmıştır. Böylece söz konusu dönemde başlayan esaslı kültür ve sanat çalışmaları neticesinde birçok sanat dalı devlet eliyle yeniden yapılandırılarak, kurumsallaştırılmıştır. Söz konusu kurumlar, Türkiye'de sanatın yücelmesi için gerekli atılımları yaparak Türkiye'nin sanatsal ve kültürel kimliğinin şekillenmesinde önemli bir rol oynamışlardır.

Türkiye Cumhuriyeti'nin sanatsal kimliğinin sağlam temeller üzerinde yükselmesini arzu eden Atatürk'ün güzel sanatlar anlayışı hiç şüphe yok ki millî ve medenî bir mahiyete sahiptir. Özünü millî kültürden alan bu anlayış, muasır medeniyet seviyesini teşkil eden Batı'nın formlarıyla işlenerek zenginleştirilen özgün bir sanat tarzını ifade etmiştir. Böylece Türk sanatçıları güzel sanatların her bir dalında yaptıkları çağdaş çalışmalar için millî tarihten olay, yer ve kişi bağlamında feyz ve ilham almışlardır.

Sonuç itibariyle şunu açıkça ifade edebiliriz ki günümüz Türkiyesi'nde; musikide, tiyatroda, sinemada, operada, balede, resimde, heykelde, mimaride, edebiyatta, dansta ve halk oyunlarında elde edilen uluslar arası başarılar hiç şüphesiz Atatürk'ün sanatı sevmesi ve sanatçıyı teşvik etmesi neticesinde açılan aydınlık Cumhuriyet yolunun birer ürünüdür. 


\section{KAYNAKLAR}

\section{Resmî Yayınlar ve Gazeteler}

Ayın Tarihi, S.12, 1934.

, C.22, S.73, 1930.

TBMM Zabit Ceridesi, C.4, 1935.

Cumhuriyet Gazetesi, “Atatürk'ün 2 Eylül 1936'da Balkan Festivali’nde Kâzım Dirik'e ve Bir Türk Çocuğuna Yazdırtıp Okuttuğu Notlar", 05.09.1936

, Cevat Abbas Gürer, "Montrö Imzalandiğı Akşam Atatürk Bu Sulh Zaferini Florya'da Nasıl Kutlamıştı,”, 10.11.1941 , Muhsin Ertuğrul, “Bir Dönüm Gecesi”,14.04.1963

Dünya Gazetesi, Hasan Cemil Çambel, 30.08.1952

Milliyet Gazetesi, Kâzım Özâlp, “Özâlp Atatürk’ü Anlatıyor”,27.11.1969

Ulus Gazetesi, B.Kemal Ünal, “Musikiye Ait Bir Not”, 10.11.1939

\section{Araştırma Eserleri, Makaleler ve Bildiriler}

Aksan, Şebnem, “Atatürk Türkiyesi'nde Bale", Atatürk ve Sanat Sempozyumu, (26-28 Ekim 1981), İstanbul Güzel Sanatlar Akademisi no:86, İstanbul, 1983.

Altay, Fahrettin, 10 Yıl Savaş ve Sonrası (1912-1922), Eylem yayınları, Ankara, 2008.

Arıburnu, Kemal, Atatürk’ten Anılar, İnkılâp yayınevi, İstanbul, 1998.

Aslanapa, Oktay, "Atatürk'ün Kültür ve Sanat Faaliyetleri”, Erdem, C.II, S.6, Atatürk Kültür Merkezi yayını, (Ayrı basım), Ankara, 1987.

Ataman, Sadi Yaver, Atatürk ve Türk Musikisi, Kültür Bakanlığı yayınları, Ankara, 1991.

,"Milletlerarasi Folklor Kongresi ve Bir Bildiri Münasebetiyle”, Türk Folkloru, C.3, S.25, 1981, s.13-14.

Atatürk'ün Fikir ve Düşünceleri, (Yayına hazırlayan: Utkan Kocatürk), Atatürk Araştırma Merkezi yayınları, Ankara, 1999.

Atatürk'ün Söylev ve Demeçleri, C.I-III, Türk İnkılâp Tarihi Enstitüsü yayınları, Ankara, 1997.

Atay, Falih Rıfkı, Çankaya, İstanbul, 1998.

Atlar, Cevat Memduh ve Diğerleri, Atatürk Türkiyesi’nde Müzik Reformu Yılları, Flarmoni Derneği yayınları, İstanbul, 1982. 
Ay, Lütfi, “Atatürk ve Tiyatro”, Devlet Tiyatrosu Dergisi, C.57, Ankara, 1973.

Batu, A., "Egli, Ernst Arnold", Eczacıbaşı Sanat Ansiklopedisi, C.1, Yapı-Endüstri Merkezi Yayınları, İstanbul, 1997.

Bayar, Celâl, Atatürk'ten Hatıralar, İstanbul, 1955.

Berk, Nurullah, “Atatürk ve Sanat”, Varlık Dergisi, S.585, 1 Kasım 1962.

Cebesoy, Ali Fuat, Sınıf Arkadaşım Atatürk, İnkılâp yayınevi, İstanbul, 1999.

Cûda, Mahmut, "Cumhuriyet Dönemi Türk Resmi”, Atatürk ve Sanat Sempozyumu, (26-28 Ekim 1981), İstanbul Güzel Sanatlar Akademisi no:86, İstanbul, 1983.

Cumbur, Müjgân, “Atatürk ve Edebiyat”, Türk Edebiyatı, C.2, S.22, İstanbul, 1973.

Çambel, Perihan, Atatürk, Evrim, Devrim ve Müzik, (IX. Türk Tarih Kongresi'nden ayrı basım), TTK.yayını, Ankara, 1984.

Çayc1, Abdurrahman, Gazi Mustafa Kemal Atatürk, Ankara, 2002.

Dal, Esin, “Atatürk Döneminde Resim ve Resim Tartışmaları”, Sanat Tarihi Yıllı̆̆ı, C.XII, İstanbul Üniversitesi Edebiyat Fakültesi Sanat Tarihi Araştırma Merkezi yayınları, (Ayrı basım), İstanbul, 1983.

Dorsay, Atilla, “Atatürk ve Sinema”, Atatürk ve Sanat Sempozyumu, (26-28 Ekim 1981), İstanbul Güzel Sanatlar Akademisi no:86, İstanbul, 1983.

Elçi, Armağan, “Atatürk Dönemi Belli Başlı Halk Müziği Araştırmacıları, Sanatçıları ve Kaynak Kişileri”, Uluslar arası Atatürk ve Güzel Sanatlar Sempozyumu Bildirileri (26-27 Ekim 2001/Ankara), Yay.Haz.: Nail Tan ve Hayrettin İvgin, Cumhuriyet, Kültür ve Tanıtma Vakfı yayınları, Ankara, 2005.

Elibal, Gültekin, Atatürk ve Resim-Heykel, İstanbul, 1973.

Erbay, Fethiye -Mutlu Erbay, Cumhuriyet Dönemi (1923-1938) Atatürk'ün Sanat Politikası, Boğaziçi Üniversitesi yayınları, İstanbul, 2006.

Ertan, Temuçin Faik ve diğerleri, Başlangıcından Günümüze Türkiye Cumhuriyeti Tarihi, Siyasal Kitabevi, Ankara, 2011.

Etike, Serap, "Atatürk ve Resim Eğitimi”, Uluslar arası Atatürk ve Güzel Sanatlar Sempozyumu Bildirileri (26-27 Ekim 2001/Ankara), Yay.Haz.: Nail Tan ve Hayrettin İvgin, Cumhuriyet, Kültür ve Tanıtma Vakfı yayınları, Ankara, 2005.

Giritli, İsmet, “Atatürk Kültür ve Sanat”, Atatürk Araştırma Merkezi Dergisi, C.IV, (Sayı 10’dan ayrı basım), Ankara, Kasım 1987.

Göçgün, Önder, Edebiyat Dünyası ve Atatürk, Atatürk Kültür Merkezi yayını, Ankara, 1995. 
Gövsa, İbrahim Alâettin, Acılar, Türkiye İş Bankası Kültür yayınları, ilavelerle 2. bask1, Ankara, 1966.

Granda, Cemal, Atatürk'ün Uşağının Gizli Defteri, Anekdot yayınevi, Ankara, 2010.

Günaydın, Günay, “Atatürk ve Müzik”, Uluslararası Atatürk ve Güzel Sanatlar Sempozyumu Bildirileri (26-27 Ekim 2001/Ankara), Yay.Haz.: Nail Tan ve Hayrettin İvgin, Cumhuriyet, Kültür ve Tanıtma Vakfı yayınları, Ankara, 2005.

Irmak, Sadi, Atatürk’ten Anılar, Ankara, 1978.

İnan, Afet, Atatürk Hakkında Hatıralar ve Belgeler, Türkiye İş Bankası yayınları, İstanbul, 2007.

İnan, Afet, Mimar Koca Sinan, Türkiye Emlâk Kredi Bankası Neşriyatı no.3, Ayyıldız matbaası a.ş, Ankara, 1968.

Kaptan, Ârif, “Atatürk ve Sanat”, Türk Dili Dergisi, C.V, S.50, 1955.

Karal, Enver Ziya, Atatürk’ten Düşünceler, ODTÜ Geliştirme Vakfı Yayıncılık ve İletişim A.Ş., Ankara, 1998. 1968. "Atatürk ve Sanat”, Devlet Tiyatrosu Dergisi, C.39, Ankara,

Kili, Suna, Atatürk Devrimi, Bir Çağdaşlaşma Modeli, Türkiye İş Bankası Kültür yayınları, 7. bask1, Ankara, 2000.

Kolukısa, Pınar, “Atatürk'ün Tiyatro Çalışmaları”, Devlet Tiyatrosu Dergisi, C.57, Ankara, 1973.

Konuk, Taciser, “Atatürk'ün Resim Sanatına Verdiği Önem ve Atatürk Portreleri”, Uluslar arası Atatürk ve Güzel Sanatlar Sempozyumu Bildirileri (26-27 Ekim 2001/Ankara), Yay.Haz.: Nail Tan ve Hayrettin İvgin, Cumhuriyet, Kültür ve Tanıtma Vakfı yayınları, Ankara, 2005.

Kurtuluş, Yıldız, “Cumhuriyet'in Kuruluş Yıllarında Türk Resminde Yurttaş Kadın Imgesi”, Uluslar arası Atatürk ve Güzel Sanatlar Sempozyumu Bildirileri (26-27 Ekim 2001/Ankara), Yay.Haz.: Nail Tan ve Hayrettin İvgin, Cumhuriyet, Kültür ve Tanıtma Vakfı yayınları, Ankara, 2005, s.82-84.

Makal, Tahir Kutsi, “Atatürk ve Folklor”, Türk Edebiyatı, İstanbul, 1980.

Memmedova, Terane, "Atatürk ve Sinema”, Uluslar arası Atatürk ve Güzel Sanatlar Sempozyumu Bildirileri (26-27 Ekim 2001/Ankara), Yay.Haz.: Nail Tan ve Hayrettin İvgin, Cumhuriyet, Kültür ve Tanıtma Vakfı yayınları, Ankara, 2005.

Mesut Cemil Anlatıyor: Nükte, Fıkra ve Çizgilerle Atatürk II, Derleyen: N.A. Banoğlu, 1954. 
Nutku, Özdemir, “Cumhuriyet Döneminde Türk Tiyatrosunu Geliştiren ilk Adımlar", Atatürk ve Sanat Sempozyumu, (26-28 Ekim 1981), İstanbul Güzel Sanatlar Akademisi no:86, İstanbul, 1983.

Ozansoy, Halit Fahri, Edebiyatçılar Çevremde, Sümerbank Kültür yayınları 5/109, Ankara, 1970.

Özgü, Melâhat, Atatürk'ün Edebiyat ve Sanat Anlayışı, Türk Tarih Kurumu basımevi, (Atatürk Konferansları'ndan ayrı basım), Ankara, 1964. , “Atatürk Sergi ve Müzede”, Türk Dili, C.12, S.46, 1 Kasım 1963.

Öztoprak, İzzet, “Atatürk, Çăğdaşlaşma ve Dış Dünyaya Etkileri”, Atatürk Araştırma Merkezi Dergisi, C.I, Ankara, Kasım 1984.

Öztoprak, Latife, “Atatürk, Sanat, Sanatçı ve Resim”, Atatürk araştırma Merkezi Dergisi, C.XIX, , S.56, Ankara, Temmuz 2003.

Refiğ, Gülper, “Atatürk Dönemi Musiki Devrimi”, Atatürk ve Sanat Sempozyumu, (26-28 Ekim 1981), İstanbul Güzel Sanatlar Akademisi yayın no:86, İstanbul, 1983.

Refiğ, Halit, “Türkiye'de Devletin Sinema Siyaseti”, Atatürk ve Sanat Sempozyumu, (26-28 Ekim 1981), İstanbul Güzel Sanatlar Akademisi no:86, İstanbul, 1983.

Saygun, Adnan, Atatürk ve Musiki, O’nunla Birlikte O'ndan Sonra, SevdaCenap And Müzik yayınları, Ankara, 1934.

Soyak, Hasan Rıza, Atatürk’ün Hususiyetleri, İstanbul, 1964.

Süslü, Azmi, "Cumhuriyet Döneminin Türk Kültürüne Bakışı ve Kültür Politikaları”, Atatürk Araştırma Merkezi Dergisi, C.XI, S.31, Mart 1995.

Şapolyo, Enver Behnan, Kemal Atatürk ve Millî Mücadele Tarihi, Ekicigil matbaas1, 3. bask1, İstanbul, 1958.

Tan, Nail, "Atatürk Döneminde Plânll Ilk Resmî Halk Müziği Derlemesi ve 'Yurdumuzun Nağmeleri' Kitabl”, Uluslar arası Atatürk ve Güzel Sanatlar Sempozyumu Bildirileri (26-27 Ekim 2001/Ankara), Yay.Haz.: Nail Tan ve Hayrettin İvgin, Cumhuriyet, Kültür ve Tanıtma Vakfı yayınları, Ankara, 2005.

Toros, Taha, Türk Hatipleri, İstanbul, 1950.

Tunçay, Mete ve diğerleri, Türkiye Tarihi 4, Çağdaş Türkiye (1908-1980), (Kolektif eser), İstanbul, 1995.

Turan, Şerafettin, Türk Devrim Tarihi, 4. Kitap Birinci Bölüm, Ankara, 1999.

Türkoğlu, Sabahattin, “Atatürk ve Folklor”, Sanat Dünyamız, Y1l:8, S.22 (Özel say1), İstanbul, 1981.

Ünal, Refik, Atatürk’ün Sevdiği Türküler, Ankara, 1973. 
Vildan Çetintaş, “Atatürk'ün Üniversite Reformu Çerçevesinde Türk Heykel Sanatındaki Gelişmeler”, Uluslararası Atatürk ve Güzel Sanatlar Sempozyumu Bildirileri (26-27 Ekim 2001/Ankara), Yay.Haz.: Nail Tan ve Hayrettin İvgin, Cumhuriyet, Kültür ve Tanıtma Vakfı yayınları, Ankara, 2005.

Yalçın, Durmuş ve Diğerleri, Türkiye Cumhuriyeti Tarihi, C.II, (Kolektif eser), Atatürk Araştırma Merkezi yayınları, Ankara, 2002.

Yazman, Aslan Tufan, “Atatürk ve Güzel Sanatlar”, Sanat Dünyamı, C.8, S.22 (Özel sayı), İstanbul, 1981.

Y1lmaz, Peker, “Atatürk ve Edebiyat”, Kemalizm, S.225, İstanbul, 1981.

Yücel, Erdem, “Atatürk ve Güzel Sanatlar”, Türk Dünyası Tarih Dergisi, C.3, S.32, İstanbul, 1989. 